\title{
MEMBRANE TECHNIQUES IN WASTEWATER TREATMENT
}

The treatment of industry wastewaters necessitates the application of a number of complementary technologies which would ensure the removal of impurities to such a degree that the treated water (wastewater) could be used again for municipal or industrial purposes with simultaneous recovery of valuable substances present in these wastewaters.

The paper presents the potentials offered by membrane techniques applied in the treatment of industrial wastewaters generated by various branches of industry. As examples, emulsion waterwater, waterwater coming from textile, pulp and paper and agro-food industries have been chosen. Also treatment of landfill leachate, removal of metals and utilization of membrane bioreactors for organics' wastewater treatment were discussed.

\section{INTRODUCTION}

Heavily industrialized areas generate wastewaters with a considerable amount of industrial substances, which contain a variety of impurities and are characterized by non-uniformity of concentration. The treatment of these wastewaters necessitates the application of a number of complementary technologies which would ensure the removal of impurities to such a degree that the treated water (wastewater) could again be used for municipal or industrial purposes with simultaneous recovery of valuable substances present in these wastewaters. The increasing pollution of environment is effected principally by a high level of industrialization, which is still rising, and by overpopulation [1].

To reduce the pollution level of environment, various technological processes can be applied, principally separation techniques. Literature provides [2-4] numerous strategies promoting the application of separation techniques in the protection and development of environment [4]:

*Silesian Technical University, Faculty of Environmental and Energy Engineering, Institute of Water and Wastewater Engineering, Konarskiego 18, 44-100 Gliwice, Poland. 
Strategy I. Technologies used in the treatment of polluted sources of surface waters, underground waters as well as municipal sewage. The strategy involves all procedures starting from water treatment to the renewal of water from wastewaters.

Strategy II. Treatment of industrial wastewaters at the place of their generation. In this case, the impurities can be recovered and further reused.

Strategy III. Integrated treatment, where separation processes are applied in a production process, contributing to the minimization of generated wastes, lower energy consumption and higher efficiency.

Strategy IV. Technologies with no waste materials (clean technology), which eliminate the use or generation of impurities.

At present, a number of processes are applied in the environment protection as treatment technologies, e.g. filtration on sand beds, adsorption, absorption, sedimentation, flocculation, extraction, precipitation, aeration, distillation, condensation, membrane processes and others [1]. The choice of an appropriate separation technique is conditioned by two factors: it must be technically feasible and attractive in view of cost-effectiveness. Frequently, to achieve the preset goal (separation), two or more separation processes must be joined (hybrid processes) $[1,2,5]$. In many cases, hybrid processes are characterized by higher efficiency and effectiveness in applications involving environment protection. Such endeavours are beneficial due to the possibility of recovering and reuseing raw materials and by-products, due to limiting the consumption of energy - directly or indirectly and due to obtaining better-quality products, or even new products.

The concept involving the application of membrane processes in the environment management is not entirely new. The successful application of ultrafiltration in the processing of whey in 1970s (strategy II) and in the electrophoretic process of metal coating (strategy III) is a proof thereof. However, at present (1990s) the application of membrane techniques to environmental purposes is gaining attention, which can be exemplified by:

- yearly expenditures in the USA for the application of membranes used in modern processes of water treatment are envisaged to increase from 40 mln US dollars to $140 \mathrm{mln}$ US dollars within the period from 1988 to $1998[1,6]$,

- the global market of membranes and membrane modules used in the technology of water or wastewater treatment is envisaged to increase from $400 \mathrm{mln}$ US dollars to about $780 \mathrm{mln}$ US dollars within the period from 1991 to $1996[1,6]$.

Due to a considerable progress in research investigations over the last 15-20 years involving the development of membrane techniques, the application of these techniques to the solution of environmental problems is technically realizable and economically effective [3]. The processes of membrane separation as well as membrane reactors have been enjoying widespread application. The integration of membrane operations with traditional technologies or the development of new production cycles based on membrane techniques is becoming a very promising field of activity for engineers of different specializations. Table 1 [4] presents the potentials for the applica- 
tion of membrane processes to wastewater treatment and removal of typical impurities allowing for the scope of their elimination.

Table 1

Application of membranes for the treatment of wastewaters allowing for the type of substance subject to treatment

\begin{tabular}{|c|c|c|c|c|c|c|c|c|c|c|c|c|c|}
\hline Compounds & MF & UF & NF & RO & ED & D & MD & PV & LM & MC & $\mathrm{H} 1$ & $\mathrm{H} 2$ & $\mathrm{H} 3$ \\
\hline $\begin{array}{l}\text { Suspension } \\
\text { Colloids } \\
\text { Macromolecular } \\
\text { organic compounds } \\
\text { Mild molecular } \\
\text { organic compounds } \\
\text { Low molecular } \\
\text { organic compounds } \\
\text { Dissolved gases } \\
\text { Salts }\end{array}$ & $\begin{array}{c}++ \\
++ \\
+\end{array}$ & $\begin{array}{c}++ \\
++ \\
++ \\
+\end{array}$ & $\begin{array}{l}+ \\
+ \\
+ \\
+\end{array}$ & $\begin{array}{c}+ \\
+ \\
+ \\
++ \\
++ \\
++\end{array}$ & ++ & $\begin{array}{l}++ \\
++\end{array}$ & $\begin{array}{c}+ \\
+ \\
+ \\
++ \\
+ \\
+ \\
++\end{array}$ & $\begin{array}{c}+ \\
++\end{array}$ & $\begin{array}{l}++ \\
++ \\
++\end{array}$ & $\begin{array}{l}++ \\
++ \\
++\end{array}$ & $\begin{array}{l}++ \\
++ \\
++\end{array}$ & $\begin{array}{l}++ \\
++ \\
++\end{array}$ & $\begin{array}{c}+ \\
+ \\
++ \\
++ \\
++\end{array}$ \\
\hline
\end{tabular}

D - dialysis, ED - electrodialysis, HI - chemical treatment + MF/UF, H2 - adsorption + MF/UF, H3 - biological treatment + MF/UF, LM - liquid membranes, MC - membrane contactors, MD - membrane distillation, MF - microfiltration, NF - nanofiltration, $\mathrm{PV}$ - pervaporation, $\mathrm{RO}$ - reverse osmosis, UF - ultrafiltration.

The application of membrane techniques in the environmental protection involves a number of advantages, which include principally the following $[1,4]$ :

- low consumption of energy,

- chemical substances are not required to be added, i.e. lack of waste streams,

- easy way to increase the scale (module system),

- separation carried out in the continuous mode,

- possibility to easily join membrane processes with other unit processes (hybrid processes),

- possibility to improve the separation properties of membranes during the operation of the system,

- separation carried out in mild environment conditions.

There are also many disadvantages, for example, a decrease of capacity effected by concentration polarization and membrane fouling, which particularly involves the processes of microfiltration and ultrafiltration [1]. Apart from this, also the limited life time of membranes and their low selectivity for a given separation problem may be regarded as disadvantageous. Membranes, in particular polymeric ones, are in many cases characterized by limited chemical or thermal resistance.

The following sections present the potentials offered by membrane techniques applied in the treatment of industrial wastewaters generated by various branches of industry. 


\section{EMULSION WASTEWATERS}

\subsection{OIL EMULSIONS}

Wastewaters which pose considerable hazard to natural environment involve wastewaters containing emulsified substances, principally derived from crude oil (e.g. oils, fats, lubrication agents). They are discharged to used waters, natural waters and to the ground, disturbing the mechanical and biological processes of wastewater purification, and they exert negative influence on the sewage system. The presence of oils disrupts the process of water treatment, lowers the quality of water for consumption, economic purposes and recreation. Therefore, it is necessary to separate oil from wastewaters, in particular from industrial wastewaters, which involves the regeneration or neutralization of oils to products neutral to the natural environment. The content of mineral oil in typical emulsion wastewaters, used cooling emulsions or cooling-lubricating ones, generated by the machinebuilding or metallurgical industry, may amount to a few dozen $\mathrm{kg} / \mathrm{m}^{3}$, and they are very often discharged without treatment and stored at waste dumps. The effectiveness of classical methods employed for the treatment of emulsion wastewaters is frequently poor, in particular when the dispersed substances are of small size and occur in low concentrations. Recently, new physicochemical methods for the liquidation of stable oil emulsions have been developed (electrochemical, pressure membrane techniques), which are widely applied in the industry, especially in the USA and West European countries [7].

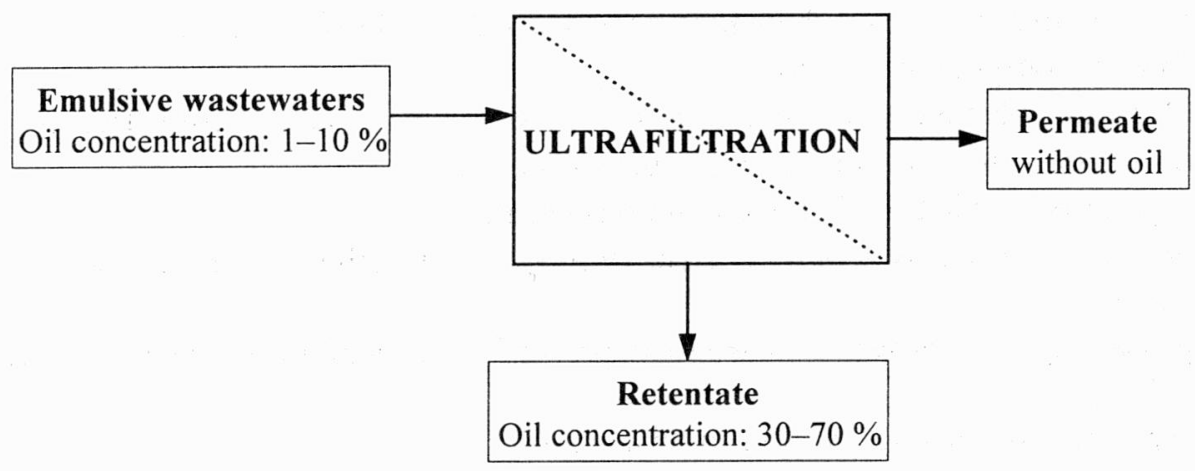

Fig. 1. Treatment of emulsion (oil) wastewaters using the ultrafiltration method

The ultrafiltration of emulsion wastewaters (Fig. 1) yields permeate devoid of oil but containing inorganic low-molecular organic compounds as well as the retentate (concentrate) of oil emulsion in water with the content of oil ranging from 30 to $70 \%$ $[5,8,9]$. The average volumetric permeate flux (capacity of the method) oscillates between ca. $1 \mathrm{~m}^{3} /\left(\mathrm{m}^{2} /\right.$ day $)$ in the course of wastewater concentration and the value ranging from $1 \%$ to $50 \%$ of the oil content [9]. The concentrated retentate is most 
frequently neutralized by burning, after additional concentration, if needed, using the centrifugal separation. Since the retentate constitutes only $5-10 \%$ of the initial volume of wastewaters, the costs of its utilization or neutralization are much lower compared to raw wastewaters, even if their burning could not be possible to carry out [9]. The content of oil in permeate is usually below $10 \mathrm{mg} / \mathrm{dm}^{3}$ [13], yet, it contains a considerable amount of low-molecular elements (corrosion inhibitors, emulsifiers, foam inhibitors), which increases the content of organic carbon [10]. There are a few effective methods for the management (treatment) of the permeate, e.g. biological methods making use of trickling filters or activated sludge methods, reverse osmosis and adsorption on active carbon or on carbon resins [9].

Figure 2 [9] presents a typical installation for the treatment of wastewaters containing oil emulsions. Before the oil emulsion is introduced into ultrafiltration modules, sedimentation suspension and non-emulsified floating oil should be removed.

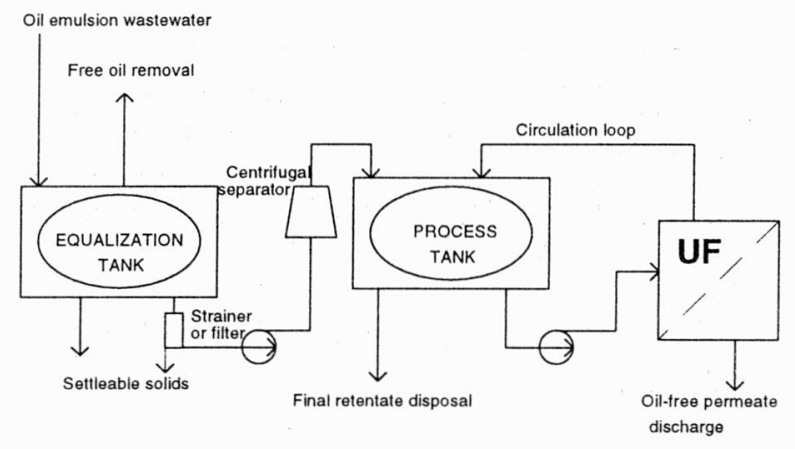

Fig. 2. Diagram of a typical installation for the treatment of wastewaters containing oil emulsions, using ultrafiltration

Mechanical removal of oil in the compensation tank (belt fender or cord fender) is applied to this purpose, or rotary brush filters, sieve filters, pressure filters or vacuum filters (removal of solids) as well as centrifugal separators (removal of oil and solids). Ultrafiltration of oil emulsions is usually carried out using the feed-bleed method, and the life time of membranes when used with wastewaters containing oil emulsions is very often longer than 4 years [9]. For the treatment of emulsion wastewaters, modules with tubular membranes are applied most frequently, since their sensitivity to the deposition of impurities is the lowest and due to the possibility of applying high-speed flows over the membrane surface, which reduces negative effects of concentration polarization [5]. After the completion of the ultrafiltration process of oil emulsions, the modules should be cleaned (regenerated). A standard procedure of regeneration consists in rinsing with hot water of $50{ }^{\circ} \mathrm{C}$, and passing a cleaning solution $(0.5 \%$ soap solution of $\mathrm{pH} 11.5$ ) through the circulation system [5]. In some cases, to remove iron compounds, acid solution is used additionally [5], and cleaning is carried out between the consecutive series (feed). The most significant impurity the mem- 
brane is coated by is oil, although also other components of the emulsion may result in fouling of the membranes.

Table 2 presents the results [8] obtained during the ultrafiltration of real emulsion wastewaters with the application of tubular membranes made of polyacrylonitrile. The treatment of emulsion wastewaters with the application of polymeric membranes is effective since both oil and total organic carbon are removed from wastewaters in $90.8-99.7 \%$, with a slight capacity drop of the membranes during the concentration process.

Table 2

Ultrafiltration treatment of wastewaters containing oil emulsions on membranes made of polyacrylonitrile

(temperature: $307-310 \mathrm{~K}$, pressure: $0.2 \mathrm{MPa}$, cross-flow velocity: $3.04-3.17 \mathrm{~m} / \mathrm{s}$ )

\begin{tabular}{|l|c|c|c|c|c|c|c|}
\hline \multirow{2}{*}{ Oil type } & \multirow{2}{*}{$\begin{array}{c}\text { Permeate flux } \\
\left(J_{v} \cdot 10^{5} \mathrm{~m}^{3} /\left(\mathrm{m}^{2} \mathrm{~d}\right)\right)\end{array}$} & \multicolumn{2}{|c|}{$\begin{array}{c}\text { Oil concentration } \\
\left(\mathrm{kg} / \mathrm{m}^{3}\right)\end{array}$} & \multicolumn{2}{c|}{$\begin{array}{c}\text { Total organic } \\
\text { carbon }\left(\mathrm{kg} / \mathrm{m}^{3}\right)\end{array}$} & \multicolumn{2}{c|}{$\begin{array}{c}\text { Dry residue } \\
\left(\mathrm{kg} / \mathrm{m}^{3}\right)\end{array}$} \\
\cline { 3 - 8 } & & Permeate & $R(\%)$ & Permeate & $R(\%)$ & Permeate & $R(\%)$ \\
\hline EN (1) oil & 3.09 & 0.204 & 94.7 & 0.540 & 97.6 & 2.73 & 58.8 \\
EN (2) oil & 2.72 & 0.118 & 99.7 & 2.62 & 98.1 & 2.76 & 93.4 \\
Prosol oil & 2.13 & 0.264 & 95.8 & 1.74 & 97.8 & 0.954 & 90.9 \\
ER oil & 3.07 & 0.089 & 98.9 & 3.85 & 90.8 & 4.79 & 65.0 \\
\hline
\end{tabular}

$R$ - retention coefficient

The application of new generation ceramic membranes considerably improves operating conditions in the treatment process of emulsion wastewaters, and allows the cleaning to be carried out at higher temperature (up to $373 \mathrm{~K}$ ) compared to polymeric organic membranes, and within wider $\mathrm{pH}$ range $(0-14)$. Table 3 presents the results [10] of testing obtained from the treatment of emulsion wastewaters containing ES/12 oil, with the application of ultrafiltration and microfiltration ceramic membrane of tubular type made by the firm TechSep (France). In the process, oil is removed completely, and the retention coefficients of dry matter and organic carbon exceed $96 \%$, with comparatively high capacity of the membranes. Ultrafiltration modules are characterized by good stability of the capacity ratio during the concentration, whereas, with respect to microfiltration membranes, the average permeate flux is observed to drop by $10-20 \%$, with the increase of emulsion concentration within $1-15 \%$.

The application of ultrafiltration in the treatment of wastewaters containing oil emulsion in water is competitive with respect to costs compared with other techniques. Operating costs under American conditions are estimated at the level of 0.50.9 US dollars $/ \mathrm{m}^{3}$ of the processed wastewaters [5], and under German conditions $-4.5-6 \mathrm{DEM} / \mathrm{m}^{3}$ [7]. Depending on the capacity of the system, investment costs are at 
the level of 1.32-12.68 US dollars $/ \mathrm{m}^{3}$ of wastewaters per day, and the operation costs $-0.08-0.21$ US dollars $/ \mathrm{m}^{3}$ of treated wastewaters [10].

Concentration of simulated wastewaters containing emulsified oil ES/12 on ceramic membranes (pressure: $0.2 \mathrm{MPa}$, cross-flow velocity: $4 \mathrm{~m} / \mathrm{s}$, temperature: $303 \mathrm{~K}$ )

\begin{tabular}{|c|c|c|c|c|c|c|}
\hline \multirow{2}{*}{$\begin{array}{c}\text { Flow yield } \\
\text { of permeate } \\
(\%) \\
\end{array}$} & \multicolumn{2}{|c|}{$\begin{array}{c}\text { Permeate flux } \\
\left(J_{v} \cdot 10^{5}, \mathrm{~m}^{3} /\left(\mathrm{m}^{2} \cdot \mathrm{s}\right)\right)\end{array}$} & \multicolumn{2}{|c|}{$\begin{array}{l}\text { Permeate concentration } \\
\qquad\left(\mathrm{kg} / \mathrm{m}^{3}\right)\end{array}$} & \multicolumn{2}{|c|}{$\begin{array}{l}\text { Retention coefficient } \\
\qquad(\%)\end{array}$} \\
\hline & Actual & Average & Dry residue & Organic carbon & Dry residue & Organic carbon \\
\hline & \multicolumn{6}{|c|}{ Organic carbon - initial concentration: $6.16 \mathrm{~kg} / \mathrm{m}^{3}$, final concentration: $48.4 \mathrm{~kg} / \mathrm{m}^{3}$} \\
\hline 16.6 & 2.43 & 2.43 & 0.101 & 0.152 & 98.7 & 97.6 \\
\hline 50.0 & 2.38 & 2.43 & 0.183 & 0.155 & 97.7 & 97.6 \\
\hline 85.0 & 2.35 & 2.43 & 0.241 & 0.221 & 96.9 & 96.4 \\
\hline 90.0 & 2.21 & 2.42 & 0.381 & 0.243 & 95.1 & 96.1 \\
\hline \multicolumn{7}{|c|}{$\begin{array}{l}\text { Microfiltration membrane }-0.45 \mu \mathrm{m} \\
\text { al concentration: } 8.23 \mathrm{~kg} / \mathrm{m}^{3} \text {, final concentration: } 128 \mathrm{~kg} / \mathrm{m}^{3} \\
\text { ial concentration: } 6.77 \mathrm{~kg} / \mathrm{m}^{3} \text {, final concentration: } 58.85 \mathrm{~kg} / \mathrm{m}^{3}\end{array}$} \\
\hline 16.6 & 7.58 & 7.58 & 0.190 & 0.150 & 97.9 & 97.5 \\
\hline 50.0 & 6.51 & 6.97 & 0.287 & 0.180 & 96.8 & 97.0 \\
\hline 85.0 & 4.68 & 6.36 & 0.405 & 0.203 & 95.5 & 96.6 \\
\hline 90.0 & 3.67 & 6.16 & 0.398 & 0.234 & 95.6 & 96.1 \\
\hline
\end{tabular}

Table 4

Total cost of the treatment of water-oil emulsion with various conceptions

\begin{tabular}{|c|c|c|c|}
\hline \multirow{2}{*}{ Processing medium/unit cost (DEM) } & \multicolumn{3}{|c|}{ Cost (DEM/year) } \\
\hline & Process 1 & Process 2 & Process 3 \\
\hline $\begin{array}{l}\text { Detergent: recovery } 85 \% \text { MF/UF. } 75 \% \text { UF; detergent cost } 2.30 \\
\text { DEM/ kg; concentration } 2 \%\end{array}$ & 138000 & 38467 & 25196 \\
\hline Water: flow $0.35 \mathrm{~m}^{3} / \mathrm{h}$. loss $10 \%$. water cost $1.20 \mathrm{DEM} / \mathrm{m}^{3}$ & 3960 & 498 & 498 \\
\hline Exploitation cost: MF/UF $11.47 \mathrm{DEM} / \mathrm{m}^{3}$. UF $15.62 \mathrm{DEM} / \mathrm{m}^{3}$ & 46860 & 46860 & 34410 \\
\hline Permeate treatment: $1.15 \mathrm{DEM} / \mathrm{m}^{3}$ & 3384 & - & - \\
\hline Retentate treatment: $329 \mathrm{DEM} / \mathrm{m}^{3}$ & 42770 & 42770 & 42770 \\
\hline Condensate treatment & 82 & - & - \\
\hline Wastewater disposal cost: $3.16 \mathrm{DEM} / \mathrm{m}^{3}$ & 9527 & - & - \\
\hline Additional cost connected with permeate returning & - & 15000 & 15000 \\
\hline Total cost & 244583 & 143595 & 117874 \\
\hline
\end{tabular}


Rautenbach $[7,11]$ carried out a comparative analysis of costs under German conditions with respect to three solutions applied in the treatment of emulsion wastewaters (Table 4):

- ultrafiltration, pretreated permeate is directed to the treatment plant-process 1 ,

- ultrafiltration with permeate returned to the process - process 2 ,

- combining micro- and ultrafiltration with permeate returned to the process - process 3 .

Basing on the obtained results $[7,11]$, the combination of micro- and ultrafiltration seems to be most economic.

\subsection{LATEX EMULSIONS}

The concentration or neutralization of latex emulsions is required to be carried out at various production stages as well as with industrial utilization of these compounds. The introduction of ultrafiltration of latex emulsions is employed conventionally in three processes [10]:

- concentration of dilute latex streams (from $0.5 \%$ to $25 \%$ ) to prevent pollution of environment and recovery of valuable latex, most frequently from the solutions left after tank cleaning processes or washing of filtration cloths [5, 12],

- cleaning of latex using diafiltration method in the process of its production to remove low-molecular impurities, e.g. oligomers, polymerization catalysts, salts,

- concentration of latex in the process of its production, between polymerization and spray-drying, to increase the content of dry mass from $30 \%$ to $60 \%$, e.g. polyvinyl chloride suspension.

Spent latex streams are not allowed to be discharged directly to the sewage system without prior treatment. The application of ultrafiltration and/or microfiltration to their treatment is competitive compared with traditional methods due to low consumption of energy (low pressure values, possibility to carry out the operation process at ambient temperature) and because the treated wastewaters are not subject to secondary fouling with chemical substances [13].

The ultrafiltration of latex wastewaters is identical with ultrafiltration of wastewaters containing oil emulsions (Fig. 1). Raw wastewaters are separated into two fluxes:

- permeate - totally devoid of latex emulsion particles, containing only lowmolecular substances present in raw emulsion,

- retentate being a concentrated solution of latex emulsions, which should be used again in the production process.

Permeate is discharged to the sewage system or is subject to further treatment.

Successful ultrafiltration process is conditioned by appropriate stability of latex emulsion. When the emulsion is stable, high value of permeate flux is obtained [12], and the process is effective in terms of capacity. Very often, however, latex emulsion undergoes destabilization, particularly with high concentrations and in effect of the 
operation of circulation pumps used in the ultrafiltration process [14]. The adjustment of $\mathrm{pH}$ is the simplest method to prepare spent latex emulsion, prior to ultrafiltration process, and to increase the stability of the emulsion [14]. The most effective way to increase the stability of latex is the addition of surface-active substances. Therefore, the addition of surface-active agents (emulsifying agent) to the feed ensures the stability of latex emulsion, even in the final stage of the ultrafiltration process. The choice of a respective surface-active agent is conditioned by its affinity with the latex structure and the interaction with the membrane [14]. The surface-active agent should neither interact with concentrated latex emulsion nor foul the membrane. The stability of latex may also decrease if the process is carried out at higher temperatures [12].

The value of permeate flux during ultrafiltration depends to a great extent on the cross-flow velocity of the flow over the membrane surface, since the process is most frequently carried out with the use of tubular modules (as for oil emulsions) $[13,15]$.

As in the case of oil emulsion ultrafiltration, after the concentration of latex emulsions, the membranes have to be regenerated (cleaned). If the latex emulsion is prepared appropriately (is stable), frequent washing with water or detergents [14] suffices to maintain constant stability and effectiveness of the process. In some cases, however, latex may form a film on the membrane surface, which cannot be removed simply by washing with detergent solution. In such cases, washing with organic solvents is applied, which in most cases effects the dissolution of latex or its swelling, allowing for the removal of the formed film from the membrane surface. For the latex from polyvinyl chloride, the following solvents are used: tetrahydrofuran, methylisobuthylketone and methylethylketone.

Table 5 presents the results of the ultrafiltration of wastewaters containing latex substances, obtained by the author of this paper, with the application of membranes made of polyacrylonitrile (PAN) and polysulphone (PSF) [13].

Table 5

Efficiency comparison of latex wastewater ultrafiltration with the tubular membranes made of polyacrylonitrile (PAN) and polysulphone (PSF)

(pressure: $0.2 \mathrm{MPa}$, cross-flow velocity: $3 \mathrm{~m} / \mathrm{s}$, temperature: $298 \mathrm{~K}$, dry matter of raw wastewaters: $10 \mathrm{~kg} / \mathrm{m}^{3}$, organic carbon in raw wastewaters: $4.75-6.82 \mathrm{~kg} / \mathrm{m}^{3}$ )

\begin{tabular}{|c|c|c|c|c|}
\hline \multirow{2}{*}{$\begin{array}{l}\text { Kind of latex } \\
\text { wastewaters }\end{array}$} & \multirow{2}{*}{$\begin{array}{c}\text { Membrane } \\
\text { type }\end{array}$} & \multirow{2}{*}{$\begin{array}{c}\text { Volume } \\
\text { permeate flux } \\
\left(J_{v} \cdot 10^{5}, \mathrm{~m}^{3} / \mathrm{m}^{2} \mathrm{~s}\right)\end{array}$} & \multicolumn{2}{|c|}{ Retention coefficient (\%) } \\
\hline & & & Dry residue & $\begin{array}{c}\text { Total organic } \\
\text { carbon }\end{array}$ \\
\hline Styrene & PAN-1 & 2.29 & 93.6 & 94.7 \\
\hline \multirow[t]{2}{*}{-butadiene (SB) } & PAN-2 & 2.01 & 96.2 & 96.9 \\
\hline & PSF-1 & 2.49 & 96.3 & 97.2 \\
\hline Styrene & PAN-1 & 0.452 & 91.1 & 89.0 \\
\hline -metacrylate (SM) & PSF-2 & 0.325 & 92.0 & 89.8 \\
\hline
\end{tabular}




\subsection{EMULSIONS OF WATER-SOLUBLE PAINTS FROM THE ELECTROPHORETIC PLATING OF METALS}

Electrophoretic painting of metals is used principally for grounding of car bodies and painting of houshold facilities. At first, anodic paints were used, but currently the process of cathode plating is being applied. The excess of paint particles is removed by washing, and the painted element is subjected to drying prior to further processing. Before the introduction of ultrafiltration, washery effluents were treated by precipitation and removal of effected deposits [16].

The application of the ultrafiltration method in the technological process of metal plating allows us to reduce the costs of painting and ensures efficient utilization of paint material, higher quality of painted elements, reduction of manual labour, prevents the pollution of environment or fire hazards. The ultrafiltration membranes retain the colloidal particles of the paint, and the permeate contains other low-molecular substances (salts, stabilizers and others) $[5,16]$. In effect, the excess of solvent and foreign ions are removed from the plating bath, paint pigments lost in washing process are recovered, environment pollution is prevented and the demand for deionized water is reduced. The most effective method for realizing the goals specified above in a single technological process is the installation of ultrafiltration facility which would directly treat the plating bath effluents $[5,16]$. Retentate is returned to the plating bath, whereby constant concentration of paint is maintained in the bath, and the permeate may be applied in the initial or in all washing stages, replacing deionized water. Closed cycle of the washing water, regenerated by permeate feeding, with simultaneous return of some water volume to the plating bath ensure in practice full recovery of the paint. Stabilizing substances present in the permeate contribute positively to the stability of paint emulsion in the washing water, whereby it can be used many times, with the same quality of paint coat maintained [10]. Figure 3 presents a typical process of electrophoretic metal plating consisting of four washing stages and ultrafiltration. Due to the application of ultrafiltration, $98 \%$ of paint is recovered, which improves economics of the process and does not result in higher pollution of environment.

In the anode system carried out in a traditional way, the plating bath contains $12-15 \%$ of solids. The obtained capacity ratios (volumetric permeate flux) during the ultrafiltration of anode paints may vary: $30-70 \mathrm{dm}^{3} / \mathrm{m}^{2} \mathrm{~h}\left(1.6-3.8 \mathrm{~m}^{3} /\left(\mathrm{m}^{2} \mathrm{~d}\right)\right)$. The differences in permeate flux are effected by the differences in chemical composition of the paints, allowing for the type of resin and the ratio of pigment compared to binding substances, as well as differences in stability, content of solids and temperature. The ultrafiltration of anode paints is comparatively simple in terms of operation. The most important requirement to follow is the maintenance of high cross-flow velocity of the flow over the membrane surface. The life time of membranes is three years on average. In most cases, the membranes are cleaned once or twice a year [10].

Due to higher content of solids (about 20\%), the ultrafiltration installation working in the catode system will be characterized by lower permeate flux (capacity), and 
therefore larger membrane surfaces will be required. In the systems working with paint for cataphoresis, the volumetric permeate flux will be $15-35 \mathrm{dm}^{3} / \mathrm{m}^{2} \mathrm{~h}(0.8-1.9$ $\mathrm{m}^{3} / \mathrm{m}^{2} \mathrm{~d}$ ), concentration of the substance emulsified in the permeate $0.1-0.5 \%$, and the concentration of solvent $2-3 \%$. The life time of membranes is above 2 years, but the installations are cleaned $1-3$ times a year [10].

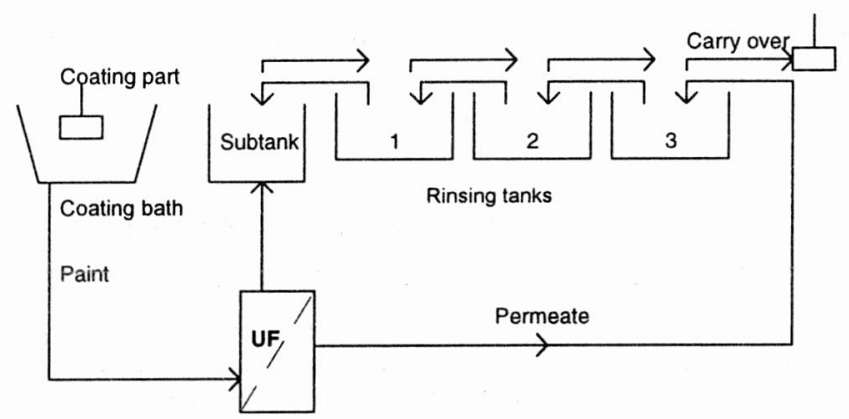

Fig. 3. Diagram of the continuous process of metal electroplating using ultrafiltration

In the ultrafiltration process of soluble paint baths, tubular modules, capillary, plate and frame as well as spiral modules can be applied. During the painting process carried out with the use of anode system, ultrafiltration membranes of small negative surface charge are used, whereas in the cataphoretic process of painting of metal elements, the application of ultrafiltration membranes with positive surface charge is recommended.

\section{WASTEWATERS FROM TEXTILE INDUSTRY}

Textile wastewaters belong to a group of industrial wastewaters containing coloured substances whose biodegradation is difficult and therefore their discharge directly to a sewage system or to environment is not possible [17].

Classical methods for the treatment of wastewaters generated by textile industry, and in particular effluents from a dye-house, involve chemical precipitation [18], process of activated sludge [18], chlorination and ozonization [18] and adsorption on active carbon [18]. Wastewaters generated by textile industry are discharged to surface waters or sewage system after intensive treatment in the plant. Due to increasing costs involving the release of impurities into environment, and allowing for the content of valuable chemical substances in wastewaters, it is beneficial to apply membrane technologies to the recovery of water, chemical substances or energy. Membrane processes may instigate the formation of closed water cycles in the plant.

Membrane processes may become alternative solutions for traditional methods involving the treatment of industrial wastewaters generated by textile industry. Ultrafiltration is used for the treatment of wastewaters containing macromolecular sub- 
stances, that is adhesive compounds and latex ones, as well as for the treatment of wastewaters effected by washing of wool or cotton, whereas the reverse osmosis may be used for the treatment of wastewaters generated by the process of cloth or fibre dyeing [17]. Table 6 presents the most important substances, which can be recovered using membrane techniques. Table 7 presents a typical quality of recovered water with the use of reverse osmosis [17]. It can be reused at each stage of the technological process in the textile industry, even for dyeing with bright colours, e.g. white [17].

Recoverable substances from textile wastewaters

\begin{tabular}{|l|l|}
\hline \multicolumn{1}{|c|}{ Process } & \multicolumn{1}{c|}{ Substance } \\
\hline Desizing & $\begin{array}{l}\text { starch, carboxymethylcellulose, poly-(vinyl- } \\
\text { alcohol), polyacrylates, water }\end{array}$ \\
Coating & $\begin{array}{l}\text { latex } \\
\text { Wool washing } \\
\text { lanoline, combustibles, soda, water } \\
\text { dyes, } \mathrm{NaCl}, \mathrm{Na}_{2} \mathrm{SO}_{4}, \text { water }\end{array}$ \\
\hline
\end{tabular}

Table 7

Average quality of water recovered from textile wastewaters by means of membrane processes

\begin{tabular}{|l|c|}
\hline \multicolumn{1}{|c|}{ Parameter } & Value \\
\hline Suspension $\left(\mathrm{mg} / \mathrm{dm}^{3}\right)$ & 0 \\
COD $\left(\mathrm{mg} / \mathrm{dm}^{3}\right)$ & 0 \\
Surface-active substance $\left(\mathrm{mg} / \mathrm{dm}^{3}\right)$ & $<1$ \\
Colour & 0 \\
Salts $\left(\mathrm{mg} / \mathrm{dm}^{3}\right)$ & $30-600$ \\
Hardness $\left({ }^{\circ} \mathrm{F}\right)$ & $<1$ \\
pH & as a feed \\
\hline
\end{tabular}

\subsection{APPLICATION OF REVERSE OSMOSIS TO THE TREATMENT OF COLOURED TEXTILE WASTEWATERS}

The dyeing process in the textile industry involves principally cotton fibres, viscose, polyester and nylon fibres and their mixtures manufactured as cloths or yarn. Wastewaters effected by the dyeing process contain alkalies, salts, unused dyes in colloidal or dissolved form, fatty acids, detergents and other organic substances as: degreasing substances, emulsified oils and fats, oxidizing and reducing agents [19]. 
The treatment of wastewaters after the dyeing process in the textile industry [19] involves principally the removal of colour and organic compounds, but also the recovery of water or mineral salts is important, and therefore in this case, the membrane processes are of the greatest significance.

The investigations carried out over last years [1, 3, 17-22] have shown that membrane processes, and in particular reverse osmosis, are appropriate techniques to solve the problem of treating the wastewaters generated by the dyeing process, and they may contribute to the recovery of valuable substances and energy. The application of dynamic membranes and also the composite membranes is recommended for this purpose [19]. In the dyeing process of clothes or fibres, a considerable quantity of hot water, often exceeding the temperature of $100{ }^{\circ} \mathrm{C}$, is used. Power constitutes about $80 \%$ of the overall energy consumption in the textile plant, whereas the costs of the dyeing process constitute $15-25 \%$ of total costs [21]. About $36 \%$ of thermal energy is lost in boilers, pipelines and due to breaks in the production process. Other losses are caused by low efficiency in terms of energy management involving particular operations, e.g. the spent dyeing bath has the temperature of about $80-90{ }^{\circ} \mathrm{C}$.

The installations for the treatment of wastewaters from the dyeing process of cotton and/or nylon and polyester fibres are based on the microfiltration process and reverse osmosis [19]. The applied wastewaters contained mixed soluble and colloidal dyes, and therefore the colloidal substance had to be removed before the introduction of wastewater onto the membrane modules. The installation involved pre-filtration, coagulation with aluminium salts, microfiltration, filtration through candle filters and reverse osmosis. Such a system is designed with the $90-95 \%$ volumetric capacity of the permeate. The obtained water is suitable to be reused in the dyeing process. The retentate is being partially returned to increase the volumetric capacity of the permeate. Sodium bisulphate and a reducing agent are added to raw wastewaters to prevent destruction of the membranes. During the microfiltration process, organic compounds are removed in $65 \%$, colour in $81 \%$ and suspension and colloids in $100 \%$. Since the permeate flux is becoming smaller several times (from 300 to $50 \mathrm{dm}^{3} / \mathrm{m}^{2} \cdot \mathrm{h}$ ), the membranes are undergoing regeneration. The results obtained from the two-stage installation for reverse osmosis are presented in Table 8 [19], and the average composition of the permeate is specified in the last line. Constant permeate flux of $15 \mathrm{dm}^{3} / \mathrm{m}^{2} \cdot \mathrm{h}$ was maintained in the installation with the transmembrane pressure being increased continuously. The regeneration of membranes was obtained after reaching the pressure of 3.5 $\mathrm{MPa}$ in the first stage and 5.5 $\mathrm{MPa}$ in the second stage. It consisted in rinsing the system, first with citric acid and then with the mixture of EDTA/polyphosphate/borax, and in the final phase with water with detergent and formalin. The permeate was being returned to the dyeing process, and its quality was satisfactory in terms of required standards.

Reverse osmosis is also recommended for the recovery of water and auxiliary chemical substances from textile effluents. The membranes used in such a system are open membranes for reverse osmosis made, for example, of polyamides of polypi- 
perazine type, produced with the application of phase inversion method by the firm Separem [10]. They are characterized by $\mathrm{NaCl}$ retention coefficient of $85-90 \%$ and average permeate flux of $55 \mathrm{dm}^{3} / \mathrm{m}^{2} \mathrm{~h}$. Figure 4 presents the diagram of the recovery process of water and $\mathrm{Na}_{2} \mathrm{SO}_{4}$ from textile effluents $\left(14 \mathrm{~m}^{3} / \mathrm{d}\right.$ capacity) with the use of membranes specified above. In the discussed system, the process of reverse osmosis was integrated with the traditional system for the treatment of textile effluents. Biological treatment effected the removal of COD and surface-active substances, whereas the physicochemical system, after which the filtration through sand bed and fine filter was taking place, lowered the content of substances contributing to membrane fouling. This prefiltration was critical in terms of the longevity aspect of membranes. The obtained results involving the treatment of effluents are presented in Table 9. The permeate may be applied in the processes of rinsing and dyeing, and the retentate, after bleaching, can be directed to the bath containing the dye.

Table 8

Effectiveness of the treatment of dye effluents using a double-stage reverse osmosis

\begin{tabular}{|c|c|c|c|c|c|c|c|c|}
\hline & ameter & $\mathrm{pH}$ & $\begin{array}{l}\text { Conductivity } \\
(\mathrm{mS} / \mathrm{cm})\end{array}$ & $\begin{array}{l}\text { Dry } \\
\text { residue }\end{array}$ & $\begin{array}{l}\text { Sodium } \\
\left(\mathrm{mg} / \mathrm{dm}^{3}\right)\end{array}$ & $\begin{array}{c}\mathrm{COD} \\
\left(\mathrm{mg} / \mathrm{dm}^{3}\right)\end{array}$ & $\begin{array}{l}\text { Organic } \\
\text { carbon }\end{array}$ & $\begin{array}{l}\text { Colour } \\
\text { ADMI }\end{array}$ \\
\hline $1^{\text {st }}$ stage & Feed & 6.3 & 1.6 & 1.50 & 372 & 250 & 68 & 230 \\
\hline of RO & Permeate & 5.8 & 0.06 & 0.05 & 7 & 29 & 11 & 23 \\
\hline & coefficient (\%) & & 96 & 97 & 98 & 88 & 84 & 90 \\
\hline $2^{\text {nd }}$ stage & Feed & 6.4 & 4.6 & 4.80 & 1175 & 770 & 233 & 320 \\
\hline of $\mathrm{RO}$ & Permeate & 5.9 & 0.09 & 0.07 & 27 & 26 & 10 & 19 \\
\hline & $\begin{array}{r}\text { Retention } \\
\text { coefficient (\%) }\end{array}$ & & 98 & 99 & 98 & 97 & 96 & 94 \\
\hline $\begin{array}{l}\text { Total } \\
\text { permeate }\end{array}$ & & 5.8 & 0.07 & 0.06 & 15 & 28 & 11 & 21 \\
\hline
\end{tabular}

ADMI - American Dye Manufacture Institute.

Table 9

Results obtained from the treatment of textile effluents on the Separem membrane

\begin{tabular}{|l|l|c|c|c|}
\hline \multicolumn{2}{|c|}{ Parameter } & Raw wastewaters & Retentate & Permeate \\
\hline Suspension, $\mathrm{mg} / \mathrm{dm}^{3}$ & & $<1$ & 43 & no \\
COD, $\mathrm{mg} \mathrm{O}_{2} / \mathrm{m}^{3}$ & & 50 & 2010 & no \\
Detergents, $\mathrm{mg} / \mathrm{dm}^{3}$ & anion & 0.35 & 10 & no \\
& non-ion & 6.8 & 260 & $<1$ \\
$\mathrm{pH}$ & & 7.8 & 8 & 7 \\
Colour & & yes & no & no \\
Sulphates $(\mathrm{VI}), \mathrm{mg} / \mathrm{dm}^{3}$ & & 1000 & 40000 & 600 \\
Hardness, ${ }^{\circ} \mathrm{F}$ & & 4 & 177 & $<1$ \\
\hline
\end{tabular}




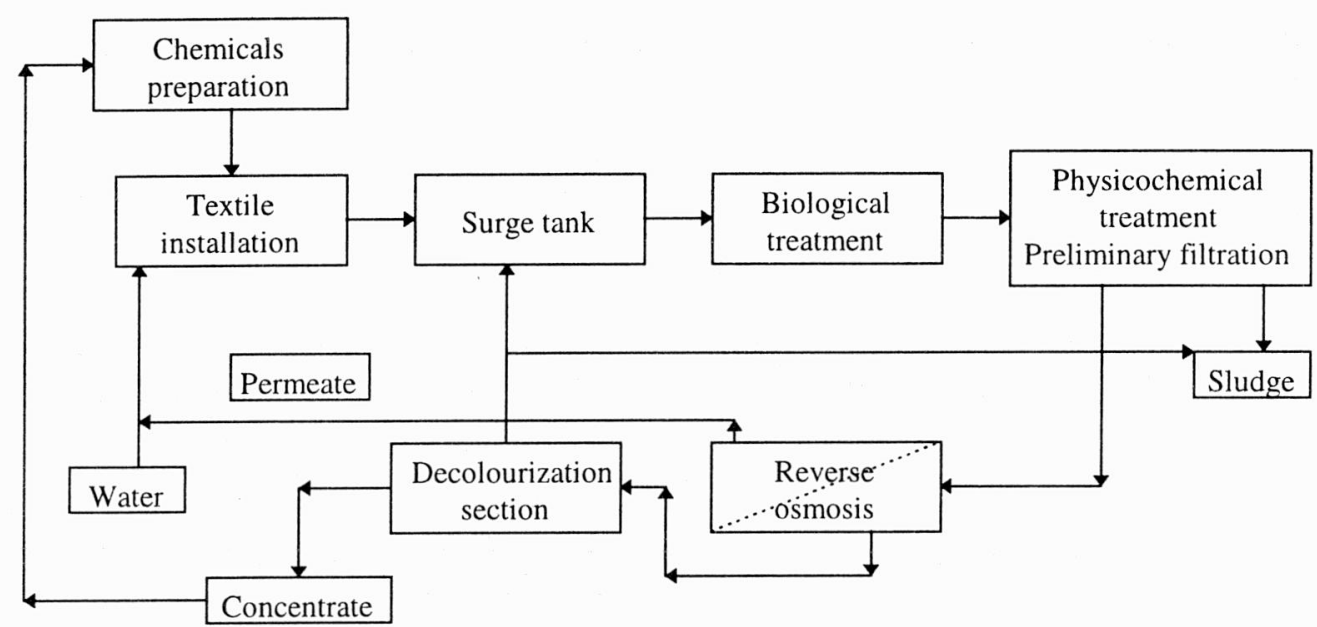

Fig. 4. Diagram of the treatment process of effluents from the dyeing installation with the recovery of water and auxiliary chemical substances

\subsection{APPLICATION OF THE INTEGRATED SYSTEM OF REVERSE OSMOSIS AND MEMBRANE DISTILLATION}

Another conception of the application of membrane techniques to the treatment of the used dyeing baths is the integrated system of reverse osmosis and membrane distillation (Fig. 5) [21, 23]. Table 10 provides the characteristics of particular streams obtained during the treatment [17]. The concentration of chemical substances in the dye-house is $10.67 \mathrm{~g} / \mathrm{dm}^{3}$ (flux No. 3), i.e. $\mathrm{NaCl}, 3 \mathrm{~g} / \mathrm{dm}^{3} ; \mathrm{Na}_{2} \mathrm{SO}_{4}, 3 \mathrm{~g} / \mathrm{dm}^{3}$; dyes, $4 \mathrm{~g} / \mathrm{dm}^{3}$ and surface-active compounds, $0.47 \mathrm{~g} / \mathrm{dm}^{3}$. The used bath has the concentration of $6.75 \mathrm{~g} / \mathrm{dm}^{3}$ (flux No. 4), assuming that only the dye is used up when it reaches the concentration of $0.08 \mathrm{~g} / \mathrm{dm}^{3}$. In effect of the concentration of the used bath using the reverse osmosis, the concentration of its components increases to the value of $57.61 \mathrm{~g} / \mathrm{dm}^{3}$ (flux No. 7), and its composition is as follows: $\mathrm{NaCl}, 24.6 \mathrm{~g} / \mathrm{dm}^{3}$; $\mathrm{Na}_{2} \mathrm{SO}_{4}, 26.28 \mathrm{~g} / \mathrm{dm}^{3}$; dyes, $0.70 \mathrm{~g} / \mathrm{dm}^{3}$ and surface-active compounds, $6.03 \mathrm{~g} / \mathrm{dm}^{3}$. When the retentate from the reverse osmosis is subjected to the process of membrane distillation (Fig. 5), the concentration of chemical substances in the concentrate may increase to $256.01 \mathrm{~g} / \mathrm{dm}^{3}$ (flux No. 9) (composition of the concentrate: $\mathrm{NaCl}, 109.39$ $\mathrm{g} / \mathrm{dm}^{3} ; \mathrm{Na}_{2} \mathrm{SO}_{4}, 116.8 \mathrm{~g} / \mathrm{dm}^{3} ;$ dyes, $3.11 \mathrm{~g} / \mathrm{dm}^{3}$ and surface-active compounds, 26 $\mathrm{g} / \mathrm{dm}^{3}$ ). The application of membrane processes is also contributing to a considerable reduction of energy consumption. Basing on the results obtained on the pilot installation and on the analysis of the concentration process of the used dyeing baths in the textile industry using the reverse osmosis, a considerable reduction of energy consumption was obtained compared with the process which did not involve the recovery of hot water and chemical substances. Also the integrated process of reverse osmosis 
and membrane distillation proved more advantageous in terms of energy consumption [21].

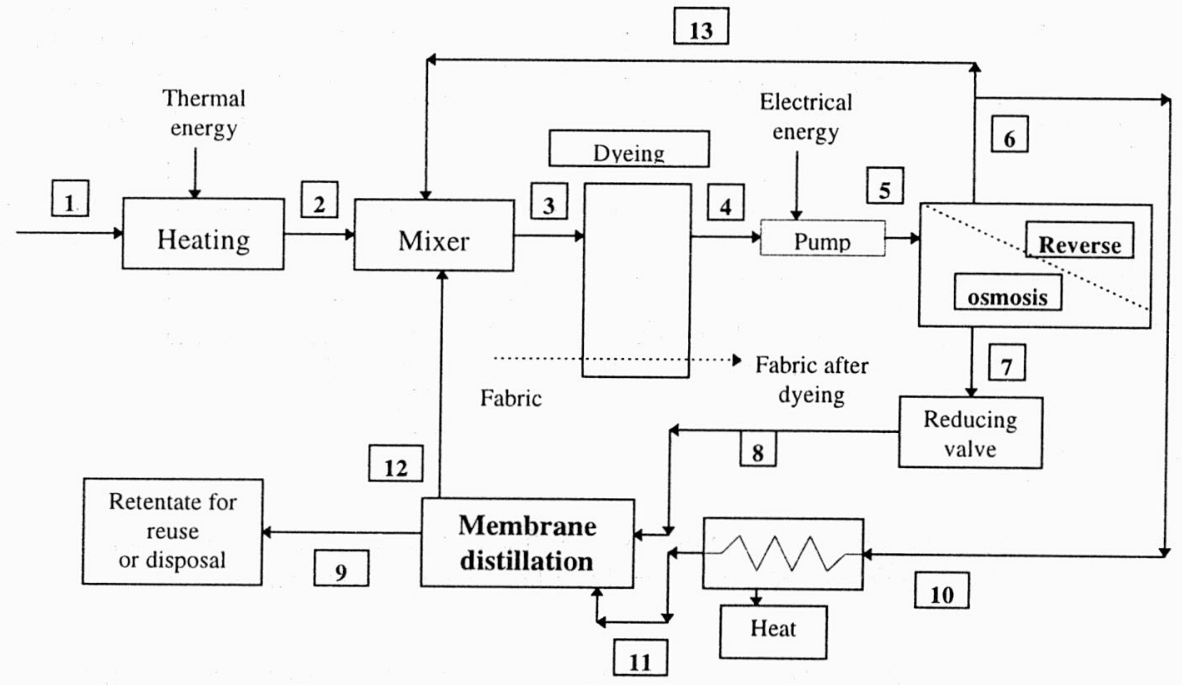

Fig. 5. Diagram of the processing of used dyeing bath with the recovery of hot water using reverse osmosis and membrane distillation

Table 10

Characteristics of streams generated in the processing of used dyeing baths using the integrated method of reverse osmosis - membrane distillation

\begin{tabular}{|c|c|c|c|c|}
\hline $\begin{array}{c}\text { No. of } \\
\text { stream }\end{array}$ & $\begin{array}{c}\text { Mass flux } \\
(\mathrm{kg} / \mathrm{h})\end{array}$ & $\begin{array}{c}\text { Temperature } \\
(\mathrm{K})\end{array}$ & $\begin{array}{c}\text { Pressure } \\
(\mathrm{MPa})\end{array}$ & $\begin{array}{c}\text { Concentration } \\
\left(\mathrm{g} / \mathrm{dm}^{3}\right)\end{array}$ \\
\hline 1 & 24.5 & 298 & 0.1 & 51.78 \\
2 & 24.5 & 348 & 0.1 & 51.78 \\
3 & 200 & 333 & 0.1 & 10.67 \\
4 & 180 & 333 & 0.1 & 6.75 \\
5 & 180 & 333 & 4.2 & 6.75 \\
6 & 160 & 333 & 0.1 & 0.39 \\
7 & 20 & 333 & 3.9 & 57.61 \\
8 & 20 & 333 & 0.1 & 57.61 \\
9 & 4.5 & 333 & 0.1 & 256.01 \\
10 & 20 & 333 & 0.1 & 0.39 \\
11 & 20 & 313 & 0.1 & 0.39 \\
12 & 35.5 & 323 & 0.1 & 0.39 \\
13 & 140 & 333 & 0.1 & 0.39 \\
\hline
\end{tabular}




\subsection{APPLICATION OF NANOFILTRATION AND ULTRAFILTRATION}

The concept of the application of nanofiltration to the treatment of wastewaters containing dyes from the textile industry [10] consists in separation (fractionation) of the components, i.e. dye and sodium salt. Since the reactive dyes are characterized by the molecular mass from 500 to $3000 \mathrm{Da}$ [18], and the cut-off of the membranes for nanofiltration is about $400 \mathrm{Da}$, there is a possibility of separating the dye from sodium salt. Both streams, i.e. permeate containing sodium salt, and retentate containing the dye, may be reused in the dyeing process. When planning nanofiltration for this purpose, high volumetric capacity of the permeate should be assumed to obtain possibly the lowest final volume of retentate containing the dye. Permeate should totally be devoid of dyeing substance, which necessitates the application of membranes characterized by high colour retention coefficient. On the other hand, the membrane must be characterized by possibly the lowest sodium salt retention coefficient to create conditions for the reuse of permeate. It has been agreed that the optimum level of colour removal, defined as the ratio of dye concentration in the permeate to that in the feed, should be 0.01 . Fulfilling such conditions, the obtainable permeate flux is $10-15 \mathrm{dm}^{3} / \mathrm{m}^{2} \cdot \mathrm{h}$.

Also the application of ultrafiltration is suggested for the recovery of dyes from textile effluents $[17,22]$. The recovery of indigo dye (Blue Jeans) using this method has become one of the most popular membrane techniques in the textile industry [5]. In the installation for such a treatment, of the capacity of $3 \mathrm{~m}^{3} / \mathrm{d}$ of effluents containing the dye (concentration of $2 \mathrm{~g} / \mathrm{dm}^{3}$ ) with the membrane surface of $54 \mathrm{~m}^{2}, 2880 \mathrm{~kg}$ of indigo can be recovered every year with the operation running for $20 \mathrm{~h} / \mathrm{day}$. The operation costs are approximately $6.20 \mathrm{DEM} / \mathrm{kg}$ of the recovered dye. Ultrafiltration membranes from polysulphone, poly(vinyl chloride) and polyacrylonitrile formed on the surface of porous polymeric rods are suitable for the treatment of effluents from the dyeing and rinsing of cloths [22]. At the pressure of $0.2 \mathrm{MPa}$, the volumetric permeate flux was $0.4 \mathrm{~m}^{3} / \mathrm{m}^{2} \cdot \mathrm{d}$ for the dyeing bath and $0.8 \mathrm{~m}^{3} /\left(\mathrm{m}^{2} \cdot \mathrm{d}\right)$ for the rinsing bath. Respective retention coefficients of organic carbon were $65-75 \%$ and $45-55 \%$, and with respect to the dyes they amounted to $100 \%$. The dyes applied in the testing were the same as those used in the textile industry.

\section{WASTEWATERS FROM THE AGRO-FOOD INDUSTRY}

The application of membrane techniques in the technology for the treatment of effluents from the food industry is attractive, not only due to environmental aspect, but also due to the possibility of recovering some valuable substances. The problem in question may clearly be exemplified on the basis of whey processing, a by-product (wastewater) generated in the process of cheese production [5, 24-28].

Whey is a liquid fraction separated from the solid substance during the production of cheese. Each $100 \mathrm{~kg}$ of milk used for the production of cheese yield $10-20 \mathrm{~kg}$ of 
cheese and $80-90 \mathrm{~kg}$ of whey [5, 24, 27]. General composition of whey is presented in Table 11 [24]. Although the particular components of whey (protein and lactose) have high utility value, it is a difficult raw product in terms of utilization due to unfavourable ratio of the quantity of lactose to the quantity of protein, and because of high biochemical oxygen demand $\left(35000-45000 \mathrm{~g} / \mathrm{dm}^{3}\right)$ it cannot be discharged to surface waters or sewage system $[9,27]$. Ultrafiltration offers potentials for improvement of this proportion in favour of protein, and other membrane processes may solve the problems involving hazards to environment.

Table 11

Composition of whey (average)

\begin{tabular}{|l|c|c|}
\hline \multicolumn{1}{|c|}{ Component } & Acid whey & Sweet whey \\
\hline Dry residue (\% mas.) & 6.60 & 6.90 \\
Protein (\% mas.) & 0.76 & 0.85 \\
Ash (\% mas.) & $0.61^{\mathrm{b}}$ & $0.53^{\mathrm{c}}$ \\
Fat (\% mas.) & 0.09 & 0.36 \\
Carbohydrates $^{\mathrm{a}}$ (\% mas.) & 5.12 & 5.14 \\
\hline
\end{tabular}

${ }^{\mathrm{a}}$ Mainly lactose. ${ }^{\mathrm{b}}$ Calcium content $-0.1 \%$. ${ }^{\mathrm{c}}$ Calcium content $-0.047 \%$.

Figure 6 presents a general diagram promoting the possibility of applying various membrane techniques to the utilization and processing of whey [24, 25].

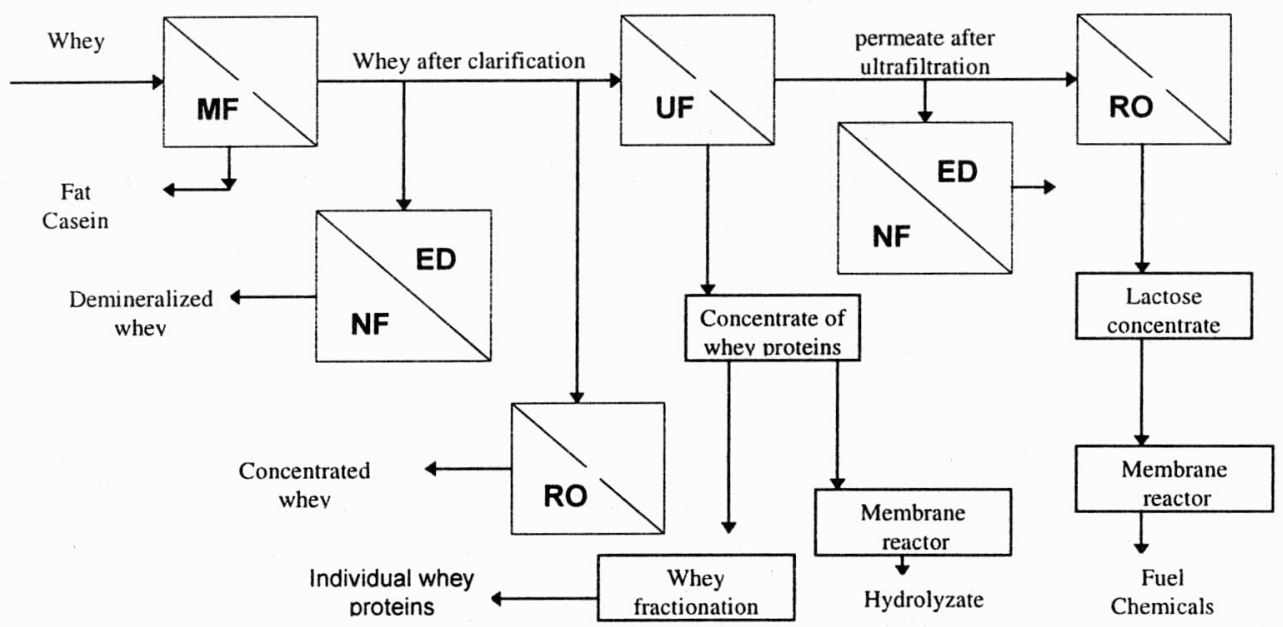

Fig. 6. Processing of whey with the application of membrane techniques: MF - microfiltration, $\mathrm{UF}$ - ultrafiltration, NF - nanofiltration, $\mathrm{RO}$ - reverse osmosis, ED - electrodialysis 


\subsection{APPLICATION OF ULTRAFILTRATION \\ TO THE UTILIZATION AND PROCESSING OF WHEY}

Since 1970, an intensive rise of protein concentrates' production from whey with the application of ultrafiltration has been observed.

The main aim of the ultrafiltration process of whey is its concentration to obtain powder of different protein contents $[5,9,10,24-30]$. If we want, for example, to obtain powder with the protein content of $35 \%$, raw sweet whey of the solid substance concentration equalling $6 \%$ is subjected to ultrafiltration until $10 \%$ dry matter is obtained containing $3.2 \%$ of protein and $0.3 \%$ of non-protein nitrogen substances [10]. Then, by the application of evaporation and spray-drying (to $96 \%$ of dry matter), we obtain powder containing $35 \%$ of protein. Maximum dry matter of the retentate amounting to about $25 \%$ allows us to obtain $60-65 \%$ of protein in the dry product [27]. Figure 7 presents the diagram of the ultrafiltration process of whey together with the quantities of the obtained retentate, permeate and final product [27].

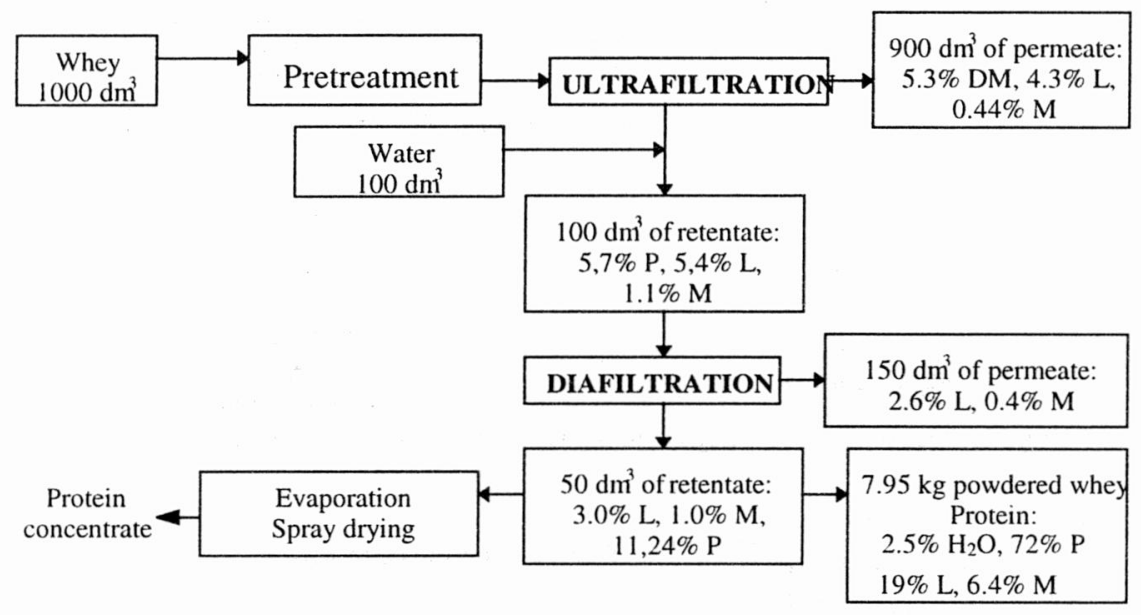

Fig. 7. Diagram of the production process of protein concentrates from whey using the ultrafiltration method: DM - dry matter, $\mathrm{P}$ - proteins, $\mathrm{L}$ - lactose, $\mathrm{M}$ - mineral substances

The characteristic of the ultrafiltration membrane is a decisive factor determining the composition and applicability properties of protein concentrates. There are three basic factors defining the characteristic of ultrafiltration membranes with respect to the above: permeate flux, easy cleaning and resistance to the development of microorganisms [10]. It has been suggested that the drop of membranes' capacity during the ultrafiltration of whey is caused by blocking the pores in with nitrogen compounds of the intermediate molecular mass [27].

\subsection{FRACTIONATION OF WHEY PROTEINS}

The separation process of pure protein fractions from whey on an industrial scale has been described by a number of authors [25, 27, 29]. In most cases, in the first 
place the whey is cooled to the temperature of $2{ }^{\circ} \mathrm{C}$ at $\mathrm{pH} 7.3$, the content of calcium should be $1.2 \mathrm{~g} / \mathrm{kg}$, and then it is quickly heated to $50^{\circ} \mathrm{C}$ over 8 minutes to precipitate lipide fraction, which is then removed using the microfiltration method. The processes of ultrafiltration and diafiltration yield the concentrate with the content of protein of $95 \%$. Particular proteins are obtained by $\mathrm{pH}$ adjustment to 3.8 , heating to the temperature of $55^{\circ} \mathrm{C}$ over 30 minutes to effect aggregation of $\alpha$-lactoalbumine, after which it is subjected to centrifugation. $\alpha$-lactoalbumine in the form of precipitate, of $80 \%$ purity, is washed with water of the temperature of $56^{\circ} \mathrm{C}$ and $\mathrm{pH} 3.8$, then it is again dissolved at $\mathrm{pH} 7$ and subjected to spray-drying. The supernatant liquid, after the $\mathrm{pH}$ adjustment to 7 , diafiltration and spray-drying, yields $\beta$-lactoglobuline of the purity $>98 \%$. One of the methods for the fractionation of whey proteins into $\alpha$ lactoglobuline and $\beta$-lactoglobuline is presented in Fig. 8 [24].

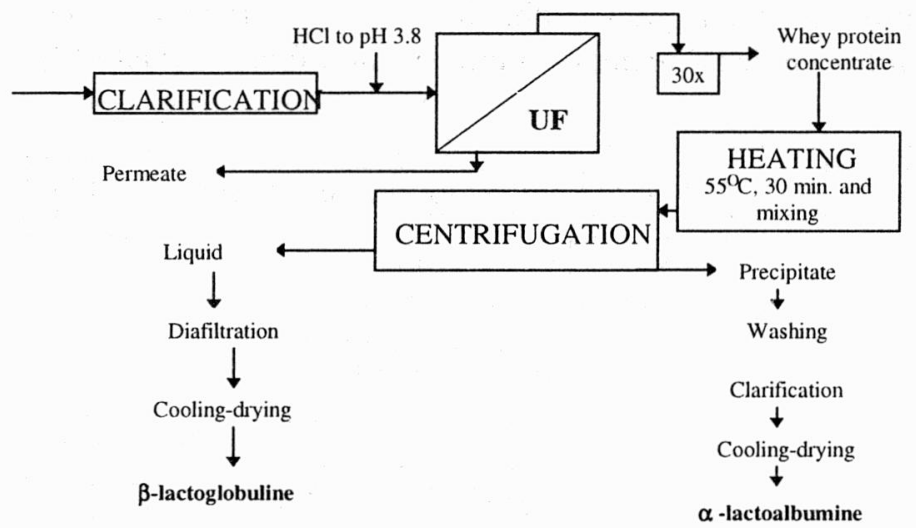

Fig. 8. Fractionation of whey proteins with the application of membranes

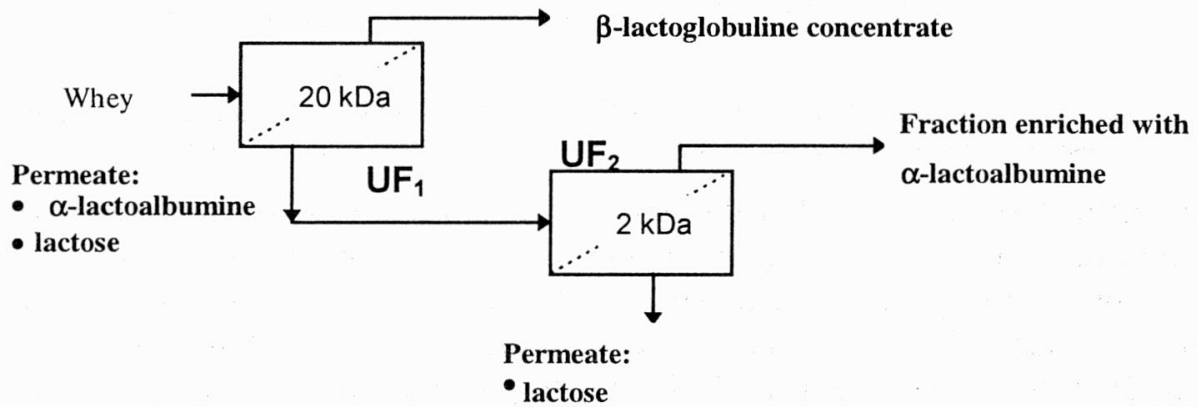

Fig. 9. Fractionation diagram of whey proteins using the ultrafiltration method

New achievements in the membrane technology allow us to carry out fractionation of most proteins differing in molecular mass present in whey by means of membrane ultrafiltration [29]. In Figure 9, whey is subjected to ultrafiltration through the membranes of the cut-off of $20000 \mathrm{Da}$, which retain $\beta$-lactoglobuline $(M w=37000)$. The 
second ultrafiltration stage is carried out with the application of membranes of the cut-off equalling $2000 \mathrm{Da}$, which effect the retention and concentration of $\alpha$-lactoglobuline $(M w=14000)$ [30].

By an appropriate selection of membranes, it is also possible to separate other valuable proteins, i.e. lactoferin, lactoperoxydase and glycopeptides, from whey [30].

\subsection{DEMINERALIZATION OF WHEY}

At present, three methods of whey demineralization are applied: ion exchange, electrodialysis and nanofiltration [24]. Due to high content of salt in whey, ion exchangers operate over short time and require regeneration, which effects the generation of large volume of post-regeneration solutions, and a considerable volume of water is required to wash out the excess of chemical substances from the applied anion exchangers. Great fluctuations of $\mathrm{pH}$ may also result in the destabilization of protein.

Electrodialysis may be here an attractive alternative [24]. Its effectiveness, kinetics of demineralization as well as the cost depend on the conductivity of the solution. With the application of electrodialysis, the total demineralization of whey is not possible due to fast increase of solution resistance during the removal of ions. Hybrid processes are often used; they combine electrodialysis to obtain the demineralization level of $50-70 \%$. After demineralization the ion-exchange process takes place. A typical composition of partially demineralized whey is presented in Table 12.

Table 12

Composition of demineralized whey

\begin{tabular}{|l|c|c|l|c|c|}
\hline Component & $\begin{array}{c}\text { Without } \\
\text { demineralization } \\
(\%)\end{array}$ & $\begin{array}{c}\text { Demineralization } \\
\text { in 55\% } \\
(\%)\end{array}$ & Component & $\begin{array}{c}\text { Without } \\
\text { demineralization } \\
(\%)\end{array}$ & $\begin{array}{c}\text { Demineralization } \\
\text { in 55\% } \\
(\%)\end{array}$ \\
\hline Protein & 26 & 30.2 & Potassium & 4.5 & 4.5 \\
Lactose & 48 & 54 & Calcium & 1.61 .1 & 1.61 .1 \\
Fat & 1.5 & 1.8 & Magnesium & 0.3 & 0.3 \\
Ash & 16 & 7 & Phosphates & 4.2 & 4.2 \\
Moisture & 2.5 & 2.5 & Chlorides & 3.2 & 3.2 \\
\hline
\end{tabular}

The introduction of nanofiltration composite membranes to the market has offered new possibilities of their applying in the processing of whey, with the focus placed on demineralization, replacing thereby electrodialysis or ion-exchange method [24, 29]. Membranes of the Film-Tech NF-40 or Desal-5 type, working under the pressure of $1.5-2.5 \mathrm{MPa}$ and at the temperature of $40-55^{\circ} \mathrm{C}$, can considerably reduce the content of $\mathrm{Na}, \mathrm{K}$ and $\mathrm{Cl}$ without the loss of other mineral or organic substances. Saline whey is concentrated to the $50 \%$ volume limit, after which diafiltration is taking place with 
constant volume until the conductivity reaches the value of $10-20 \%$ of the initial conductivity, which means that $80-90 \%$ of $\mathrm{K}$ ions or $\mathrm{Na}$ ions are removed. The desalinated whey is then concentrated to $25 \%$ of its initial volume, which in effect results in the $95 \%$ removal of salt, and since the composition of the whey is similar to the composition of sweet whey, it can be directed to the regular line of whey processing. To prevent the decrease of permeate flux during the above process, a single-stage process should be applied, and diafiltration should be carried out by adding water at the ratio by $50 \%$ lower then the ratio of permeate removal. The process results in the $90 \%$ demineralization, and the final volume constitutes $22.5 \%$ of the initial volume.

\section{MEMBRANE TECHNIQUES IN THE PULP AND PAPER INDUSTRY}

The pulp and paper industry is generating considerable quantities of heavily polluted effluents amounting to $100 \mathrm{~m}^{3} /$ ton of the processed mass. It is therefore very difficult to meet very stringent regulations concerning the protection of environment when only traditional treatment techniques such as coagulation and activated sludge are applied in their treatment. The present situation offers vast potentials for the application of membrane processes. However, their application on industrial scale is relatively small. There are probably only three installations applied in the industry on large scale operating in full time cycle [9]. Two of them are ultrafiltration installations for the processing of bleaching effluents and the third was applied to the recovery of lignosulfonates from liquors. Nevertheless, intensive investigations are carried out in research centres and in the industry on the application of ultrafiltration and reverse osmosis to the processing of cellulose effluents [10,31-34]. They are principally concentrated on: the treatment of bleaching effluents from sulfate mills, concentration of waste sulfite liquors, recovery of lignin from black liquors, processing of wastes from the semi-chemical method of wood pulping, processing of effluents from paper production machines (white waters) and the resinification of effluents from cellulose washing.

\subsection{EFFLUENTS FROM CELLULOSE BLEACHING}

In order to obtain white paper, the cellulose pulp must be subjected to a bleaching process. In practice, multi-stage mixed bleaching with pure chlorine and calcium chlorate(I) is applied. In modern plants, chlorate(I) is partially replaced by chlorine dioxide, and the bleaching process is carried out in five stages (chlorinating, alkaline extraction, chlorine(I) and twice chlorine dioxide). After each stage, the cellulose pulp is thoroughly washed and filtered out. During the first stage of bleaching, chlorinating (the so-called stage $\mathrm{C}$ - acidic), lignin is partially degraded and dissolved. More lignins dissolve during the second stage of bleaching - alkaline extraction (the socalled stage E), where the pulp is subjected to processing using the $2 \%$ solution of 
$\mathrm{NaOH}$ at the temperature of $60-70^{\circ} \mathrm{C}$ [34]. Figure 10 presents schematic diagrams of streams passing through the stages $\mathrm{C}$ and $\mathrm{E}$, in the average-size bleaching system applying the ultrafiltration process.

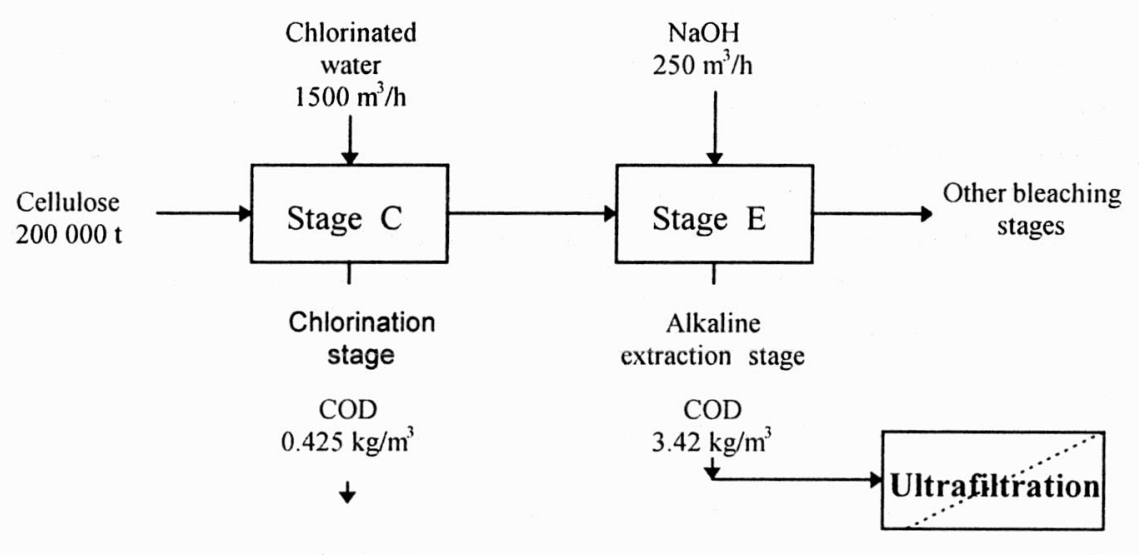

Fig. 10. Flow of streams through stages $\mathrm{C}$ and $\mathrm{E}$ of the bleaching installation

Apart from chlorine compounds, wastewater from the bleaching process contains also majority of coloured substances discharged from cellulose plants, and they are characterised by high percentage of total COD and BOD of general wastewaters. The greater part of wastewater from bleaching installations is generated by effluents from stages $\mathrm{E}$ and $\mathrm{C}$, and the sewage generated by further bleaching stages is considerably smaller. The total content of total organic chlorine compounds (TOCl), coloured substances and also COD and BOD in wastewaters may be reduced by the application of ultrafiltration. The ultrafiltration of filtrate after the first stage of alkaline extraction (Fig. 10) allows us to obtain the $60-70 \%$ reduction of TOCl and COD and $80-90 \%$ reduction of colour.

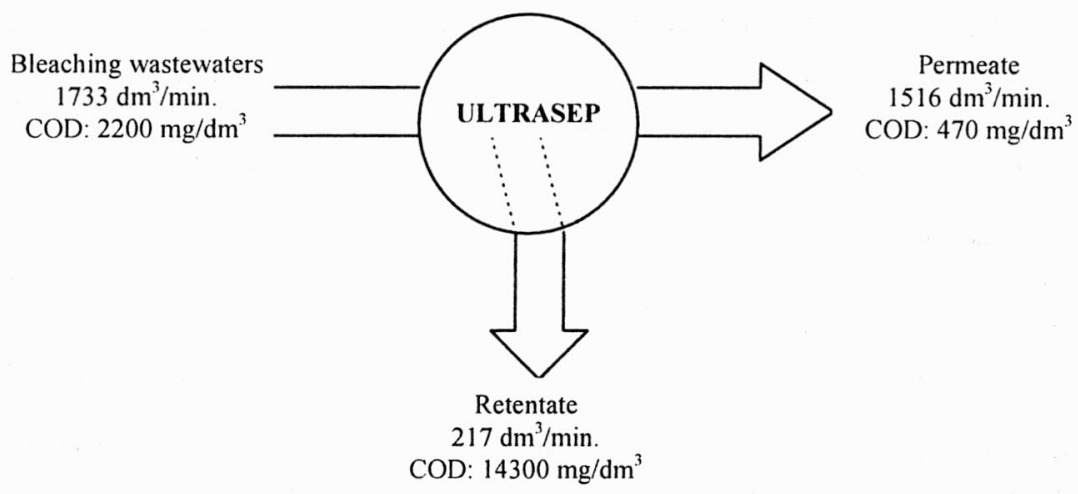

Fig. 11. Ultrafiltration installation at Sanyo Kokusaku (COD reduction: $80 \%$; colour reduction $>90 \%$ ) 
Two industrial ultrafiltration installations processing wastewaters after alkaline extraction have been in use in Japan since 1981 [52]. The ultrafiltration installation at Taio Paper Co has the capacity of $3600 \mathrm{~m}^{3} /$ day; it is equipped with tubular membranes of the firm Nitto, and the area of membranes is $1480 \mathrm{~m}^{2}$. The area of the membranes in the installation located at Sanyo Kokusaku (Iwakuni Plant) is $672 \mathrm{~m}^{2}$, and the capacity is equal to $2500 \mathrm{~m}^{3} /$ day. It was furnished with original, flat membranes manufactured by the Danish firm DOW-Chemical. Figure 11 provides some data involving this installation.

Having in mind the above considerations, it is clearly seen that the ultrafiltration process is an effective tool allowing us to lower the pollution level of wastewater left after the stage $\mathrm{E}$ (alkaline extraction). The processing of wastewater involving the stage $\mathrm{C}$ with the use of ultrafiltration is much more difficult.

\subsection{WASTE DIGESTING LIQUORS}

In the course of cellulose production process, about $50 \%$ of the input wood material remains in waste digesting liquors. A typical content of substances dissolved in digesting liquors generated by a modern pulp mill is $15-16 \%$. A bulk of substances dissolved in waste sulfite liquors is constituted by lignosulfonates, and in black liquors - by alkalignin referred to as sulfate lignin. The composition of digesting liquors differs, depending on the type of wood subject to processing and a digesting method applied, but generally, dry matter of waste sulfite liquors contains approximately: $60 \%$ of lignin, $30 \%$ of reducing sugars and $10 \%$ of inorganic substances; and that of black liquors: $41-50 \%$ of sulfate lignin, $28 \%$ of hydroxy acids and lactones, small quantities of acetic acid and formic acid, and about $20 \%$ of inorganic substances.

Table 13

Ultrafiltration fractionation of sulfite liquors with the application of tubular membranes from poly(vinyl chloride) (temperature: $298 \mathrm{~K}$, permeate recovery: $80 \%$, pressure: $0.4 \mathrm{MPa}$ )

\begin{tabular}{|l|c|c|c|c|c|}
\hline \multirow{2}{*}{ Effectiveness } & Raw & \multirow{2}{*}{$\begin{array}{c}\text { Rermeate } \\
\end{array}$} & Retentate & \multicolumn{2}{c|}{ Retention coefficient (\%) } \\
\cline { 5 - 6 } & - & 0.320 & - & Average & To the liquor \\
\hline Permeate flux $\left(\mathrm{m}^{3} / \mathrm{m}^{2} \cdot \mathrm{d}\right)$ & 87.3 & 58.65 & 203 & - & - \\
Dissolved substances $\left(\mathrm{kg} / \mathrm{m}^{3}\right)$ & 41.3 & 19.3 & 119.5 & 76.0 & 32.8 \\
Lignins $\left(\mathrm{kg} / \mathrm{m}^{3}\right)$ & 18.2 & 19.1 & 17.3 & - & 53.3 \\
Sugars $\left(\mathrm{kg} / \mathrm{m}^{3}\right)$ & 109 & 58.1 & 274 & 69.7 & - \\
COD $\left(\mathrm{kg} / \mathrm{m}^{3}\right)$ & & &
\end{tabular}

Sulfite liquor can be separated with the application of ultrafiltration into two noble fractions containing lignin compounds and sugars. Black liquor subjected to ultrafiltration concentration yields concentrates of macromolecular sulfate lignin. If we additionally apply diafiltration, the ratio of lignins to sugars in the retentate may in- 
crease during the ultrafiltration of sulfite liquor. In the course of direct ultrafiltration, the attainable purity of lignosulfonates is approximately $80 \%$. When diafiltration is applied in the installation, we obtain retentate with the content of dissolved substances of $25 \%$ and $95 \%$ level of lignin purity. The results are the same in the case of ultrafiltration with diafiltration of black liquors. Direct ultrafiltration yields the concentrates of the sulfate lignin purity level of about $80 \%$, whereas its combination with diafiltration gives the value of $90 \%$.

Table 13 presents data involving the fractionation of sulfite liquors on membranes from polyvinyl chloride [10].

Table 14 presents the fractionation results of black liquor on polyacrylonitrile membranes using the ultrafiltration method $[32,33]$.

Table 14

Ultrafiltration and diafiltration (continuous method) of black liquors (pressure: $1.0 \mathrm{MPa}$ )

\begin{tabular}{|l|c|c|c|c|c|c|c|}
\hline \multirow{2}{*}{$\begin{array}{c}\text { Loading } \\
\text { parameter }\end{array}$} & \multirow{2}{*}{$\begin{array}{c}\text { Raw } \\
\text { liquor }\end{array}$} & \multicolumn{2}{c|}{ Ultrafiltration I } & \multicolumn{2}{c|}{ Diafiltration } & \multicolumn{2}{c|}{ Ultrafiltration II } \\
\cline { 3 - 8 } & & $\mathrm{UF}$ & $\mathrm{K}$ & $\mathrm{DF}$ & $\mathrm{K}$ & $\mathrm{UF}$ & $\mathrm{K}$ \\
\hline $\begin{array}{l}\text { Dissolved } \\
\text { substances }\left(\mathrm{kg} / \mathrm{m}^{3}\right)\end{array}$ & 158.5 & 90.1 & 216.6 & 61.0 & 154.2 & 57.9 & 275.3 \\
$\begin{array}{l}\text { Lignins }\left(\mathrm{kg} / \mathrm{m}^{3}\right) \\
\begin{array}{l}\text { Organic } \\
\text { carbon }\left(\mathrm{kg} / \mathrm{m}^{3}\right)\end{array}\end{array}$ & 74.8 & 35.1 & 125.4 & 30.0 & 111.9 & 24.1 & 237.5 \\
$\begin{array}{l}\text { Lignin purity } \\
\text { degree }(\%)\end{array}$ & 50.2 & 22.3 & 75.4 & 17.9 & 66.4 & 15.0 & 98.1 \\
\hline
\end{tabular}

UF, DF - ultrafiltrate, diafiltrate, $\mathrm{K}$-concentrate.

\section{RECOVERY OF METALS FROM WASTEWATERS}

Over the last ten years, a great interest in separation techniques allowing us to recover metal ions from industrial process effluents can be observed. Conventional methods such as precipitation, extraction or ion exchange have many shortcomings, especially with respect to processing of large-volume fluxes containing low concentration of metal ions. Now they are most frequently precipitated as hydrated metal oxides or hydroxides, sulfides or xanthates with the use of flocculation or coagulation. One of major problems pertaining to the precipitation process involves the formation of substantial quantities of sludge containing metals [35]. Very often the concentration of metal ions in the filtrate after the final filtration process is still maintained at the level of several $\mathrm{mg} / \mathrm{dm}^{3}$. 
The assistance in solving these problems most frequently comes from such membrane techniques applied on the industrial scale as: reverse osmosis, nanofiltration, ultrafiltration, dialysis, electrodialysis and pertraction process.

\subsection{REVERSE OSMOSIS}

Metal ions can successfully be removed from solutions using reverse osmosis and/or nanofiltration since membranes applied in these processes retain all dissolved salts within the size from $0.01 \mu \mathrm{m}$ to $0.0001 \mu \mathrm{m}$. In many cases, these processes are viewed as an attractive alternative for conventional technologies used so far, both with respect to environmental protection and the economic aspect of the process [10].

The application of reverse osmosis to the solution of the problems specified above can be exemplified by treatment procedure involving wastewaters from the electroplating industry (Fig. 12) [36].

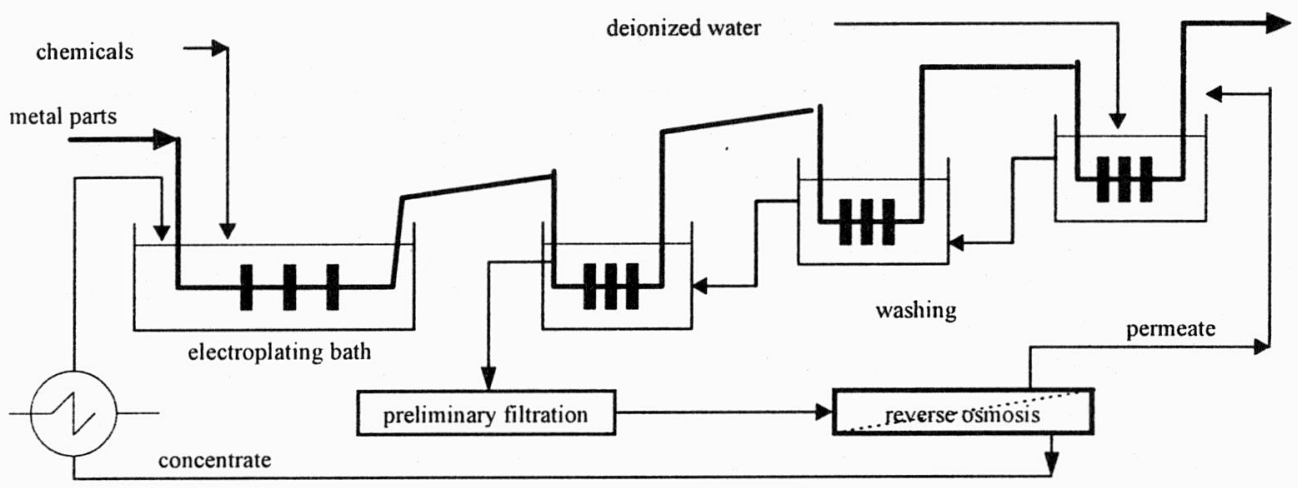

Fig. 12. Diagram of the electroplating process line integrated with reverse osmosis

The wastewaters consist mainly of washery effluents effected by a washing process of the products after the electroplating process, where the products are covered with a metallic coating, and from used electroplating baths. The volume of wastewaters from the washing process and their loading vary, and depend on the volume of water used in these processes, the way and intensity of washing as well as on the quantity of electroplating bath remaining on the surface of the coated products. The concentration of metal ions in wastewaters ranges from 0.025 to $1 \mathrm{~kg} / \mathrm{m}^{3}$, with the applied quantity of $1.5-7.6 \mathrm{~m}^{3} / \mathrm{h}$ [10]. Most frequently the electroplating effluents are characterised by the occurrence of chromium ions, copper, cadmium, zinc, nickel, lead and silver, and since the metal-coating technologies are based to a great extent on cyanide solutions, hence toxic cyanide anions are often present in these wastewaters. Traditional methods for the neutralization of such wastewaters are very expensive and complex. They necessitate the introduction of various complicated operations to recover and return metal ions to the technological process. Therefore, in this case, the 
process of reverse osmosis is much more advantageous than classical methods since it allows the recovery of water which has a very high purity level, and which in many cases can directly be returned to the technological process without additional treatment, and the concentrated solution of metal ions may be reused for filling up the electroplating bath [10].

\subsection{ELECTRODIALYSIS}

Electrodialysis is particularly useful and very often used for the treatment of washery effluents and wastewaters from electroplating plants $[10,18,37]$. In a typical installation for electrochemical metal coating, the processed components are subjected to a multi-stage washing process. In the course of such a washing process, washery effluents with high concentration of metal are generated, which may be subjected to treatment with the use of electrodialysis (Fig. 13). The concentrate, which is a condensed solution of metal ions, is used for filling up the electroplating bath, whereas the dialysate is returned to the washing installation. Hence, practically the whole quantity of water and salts present in washery effluents can be utilized [18]. Recently, the application of electrodialysis to the recovery of metals from dilute electroplating wastewaters has been gaining attention, especially in the USA [18].

The electrodialysis process has successfully been applied in the system presented above in the installations for electroplating with such metals as $\mathrm{Au}, \mathrm{Pt}, \mathrm{Ni}, \mathrm{Ag}, \mathrm{Pd}$, $\mathrm{Cd}, \mathrm{Zn}$ and $\mathrm{Sn} / \mathrm{Pb}$. The solution of metal salt can be condensed to the concentration equal to the concentration of this component in the electroplating bath, e.g. for $\mathrm{Ni}$ from $1 \mathrm{~g} / \mathrm{dm}^{3}$ to $60 \mathrm{~g} / \mathrm{dm}^{3}$ [18]. It is much more than with the application of reverse osmosis. The principal disadvantage of electrodialysis is the inability to remove simultaneously the non-ion substances (e.g. organic compounds) from the dilute stream, which can be done with the use of reverse osmosis.

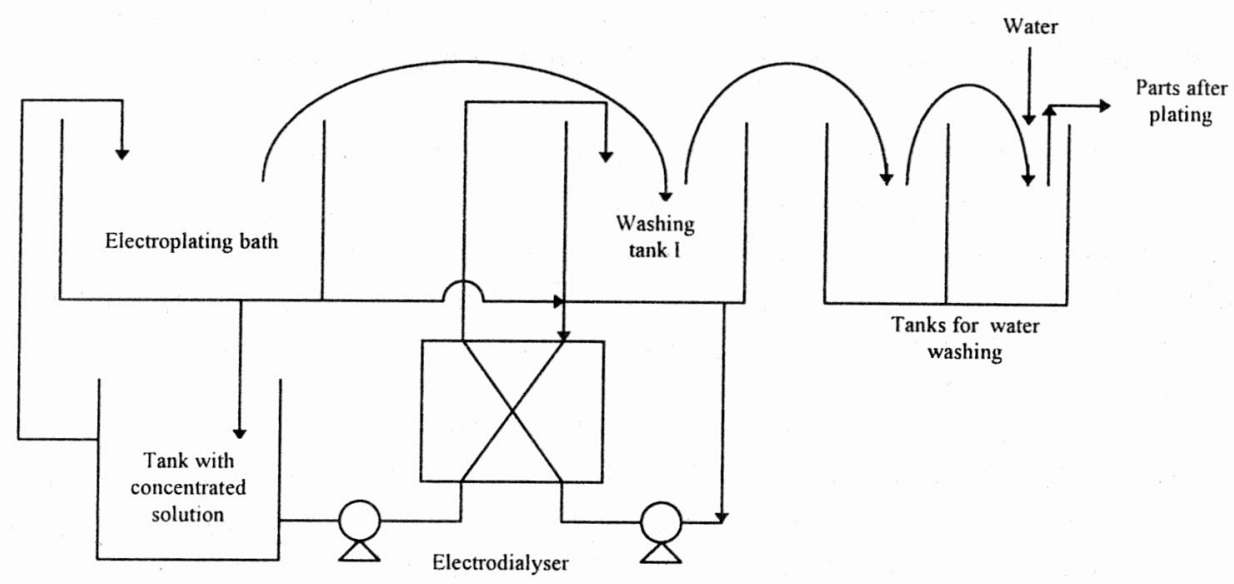

Fig. 13. Typical installation for metal electroplating with the application of electrodialysis 


\subsection{LIQUID MEMBRANES (PERTRACTION)}

Great potentials involving the separation of metal ions are offered by the application of liquid membranes (pertraction). This technique is used for the recovery of noble metals and semi-noble metals, metals of alkaline earths and rare earths as well as toxic and radioactive metals from wastewaters and other industrial effluents [38, 39]. The bulk of the carried out investigations have been devoted so far to copper ions, both from acid and alkaline effluents [40]. In the course of this process, the solution containing copper ions is introduced as feeding phase (donor phase). The membrane is constructed as an organic phase equipped with a carrier (extraction solvent) reacting reversibly with the component being washed out. The receiving phase (acceptor phase) is most frequently made up by sulfuric acid. Neither the feeding phase nor the receiving one dissolves in the liquid membrane. The driving force of the process is constituted by the $\mathrm{pH}$ gradient between water phases separated by the liquid membrane. Along the separation surface between the donor/membrane phases, liquid copper ions join with the particles of the carrier, liberating an equivalent quantity of hydrogen ions. Transport of the carrier-copper complex within the liquid membrane is carried out in the form of diffusion. On the separation surface between the membrane/acceptor phases, the liberation of copper cations is taking place with simultaneous joining of hydrogen ions with carrier particles. The extraction process is again repeated.

\subsection{APPLICATION OF HYBRID PROCESSES}

With the application of membrane processes, only the separation or concentration of a given component from the liquid system is effected, but it does not eliminate the component from the system. However, the application of membrane techniques combined with other chemical or physicochemical processes (hybrid processes) is very often more efficient compared with single processes, and they are characterized by lower operation and investment costs, with the same or higher effectiveness.

\subsubsection{Hybrid system: chemical precipitation-ultrafiltration}

The example is the removal of chromic ions during the process of chemical precipitation combined with ultrafiltration from two wastewater types, that is from electroplating effluents and from wastewaters generated by the extraction of gold from mineral ores. Chemical composition of these effluents and wastewaters is presented in Table 15 [35].

In the case of electroplating effluents, $\mathrm{Cr}(\mathrm{VI})$ present in these wastewaters in the form of chromate was reduced in the first phase to $\mathrm{Cr}(\mathrm{III})$ by means of $\mathrm{Na}_{2} \mathrm{~S}_{2} \mathrm{O}_{5}$ or $\mathrm{FeCl}_{2}$, and then precipitated with sodium hydroxide. Next, the solution containing $\mathrm{Cr}(\mathrm{OH})_{3}$ was subjected to ultrafiltration in the tubular module equipped with polysulphone membranes of the cut-off of $20000 \mathrm{Da}$ under the pressure of $0.1-0.33 \mathrm{MPa}$. 
Wastewaters generated by the extraction of gold from mineral ores, apart from chromium and other metals, contained also cyanides which had to be oxidized to $\mathrm{CNO}^{-}$by means of $\mathrm{NaCl}$, since otherwise, chromium was bonded into a complex and its precipitation in the form of hydroxide was not possible. Wastewaters with the precipitated hydroxides were also subjected to ultrafiltration in modules equipped with spiral membranes from polysulphone of the cut-off of 20000 Da under the pressure of $0.1-0.5 \mathrm{MPa}$. A diagram of the hybrid system applied during the testing is presented in Fig. 14.

Chemical composition of electroplating effluents

and wastewaters from the extraction of gold from mineral ores

\begin{tabular}{|c|c|c|c|}
\hline \multicolumn{2}{|c|}{$\begin{array}{l}\text { Galvanic wastewaters after washing } \\
\text { metals coating with chromium }\end{array}$} & \multicolumn{2}{|c|}{$\begin{array}{l}\text { Wastewaters generated in gold } \\
\text { extraction from mineral ores }\end{array}$} \\
\hline Anions $\left(\mathrm{mg} / \mathrm{dm}^{3}\right)$ & Cations $\left(\mathrm{mg} / \mathrm{dm}^{3}\right)$ & Anions (mg/dm ${ }^{3}$ ) & Cations $\left(\mathrm{mg} / \mathrm{dm}^{3}\right)$ \\
\hline $\begin{array}{l}\mathrm{CrO}_{4}{ }^{2-}-1070 \\
\mathrm{Cl}^{-}-3.9 \\
\mathrm{PO}_{4}{ }^{3-}-43.7 \\
\mathrm{SO}_{4}{ }^{2-}-43.3 \\
\mathrm{NO}_{3}{ }^{-}-24.8 \\
\mathrm{~F}^{-}-1.3\end{array}$ & $\begin{array}{l}\mathrm{Na}^{+}-285.2 \\
\mathrm{Ca}^{2+}-210.0 \\
\mathrm{~Pb}^{2+}-186.5 \\
\mathrm{Zn}^{2+}-36.3 \\
\mathrm{Cu}^{2+}-0.32\end{array}$ & $\mathrm{CN}^{-}-988.0$ & $\begin{array}{l}\mathrm{Cr}^{3+}-104.2 \\
\mathrm{Ni}^{2+}-29.4 \\
\mathrm{Zn}^{2+}-45.6 \\
\mathrm{Cu}^{2+}-31.8\end{array}$ \\
\hline
\end{tabular}

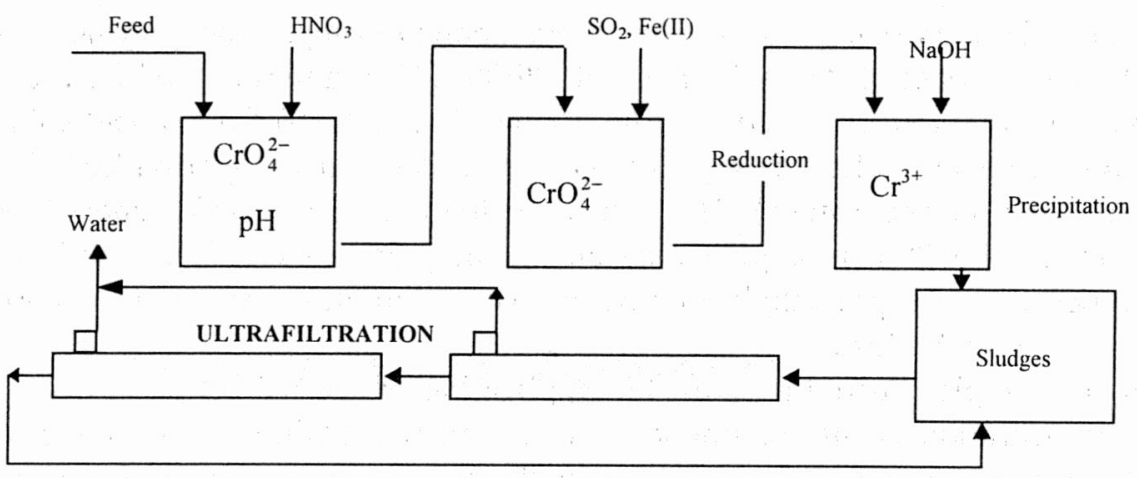

Fig. 14. Diagram of the hybrid system: precipitation

- ultrafiltration for the removal of chromium(VI) ions

\subsubsection{Hybrid system: complexing - ultrafiltration:}

An interesting solution for the separation of metal ions from the solutions is combining the low-pressure membrane processes of micro- or ultrafiltration with metal 
complexing by means of macromolecular ligands [10]. Polymer which is a ligand should be selective and characterized by good ability to bond separated ions and should be soluble in water. The following compounds are most frequently applied to the complexing process: polyethyleneimine, poly(vinyl alcohol), polyacrylic acid and copolymers of maleine acid and acrylic acid, as well as copolymers of maleine acid and ethylvinyl ether [10]. The separation of metal ions is carried out after they have been bonded into complexes of sufficiently large size to be retained by a micro- or ultrafiltration membrane. During the process, apart from permeate, the solvent and non-complexed ions are carried off, and the concentrated polymer complex with the metal to be removed remain in the system. Since the bonding of metal ions by means of polymer ligands is an equilibrium process, by disturbing the equilibrium the retentate may be subjected to regeneration to recover the metal and the complexing agent. A diagram explaining the functioning of such a hybrid process in presented in Fig. 15 [10].

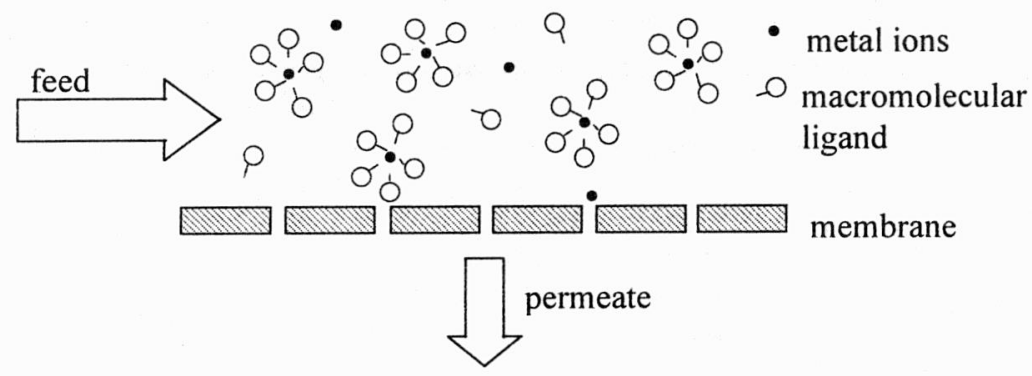

Fig. 15. Diagram of the hybrid process of complexing-ultrafiltration

Due to its ability to form stable complexes with metal ions, polyethyleneimine $\left(-\mathrm{CH}_{2}-\mathrm{CH}_{2}-\mathrm{NH}-\right)_{x}$ is one of most commonly applied complexing polymers. Most frequently, the polymer of the molar mass of $30000-60000 \mathrm{~g} / \mathrm{mol}$ is used for the separation of such metal ions as: $\mathrm{Cu}(\mathrm{II}), \mathrm{Cd}(\mathrm{II}), \mathrm{Ni}(\mathrm{II}), \mathrm{Co}(\mathrm{II}), \mathrm{Zn}(\mathrm{II})$ from model solutions [41], from solutions left after the separation of precipitated metal hydroxides [42], and from ground and surface waters [43]. In all cases, high retention coefficients of metals were obtained $(95-99 \%)$ at the $\mathrm{pH}$ values during the process exceeding 4 or 5 . At the $\mathrm{pH}$ value below 3 , the polyethyleneimine ability to complex metal ions is abruptly reduced or even totally lost.

Another example illustrating potential application of the hybrid process of complexing-ultrafiltration is the treatment of wastewaters containing radioactive waste $[10,44]$. Such wastes are generated principally by nuclear power engineering and radiation chemistry (production of radionuclides and nuclear fuel). The process of their neutralization consists in reducing the volume of these wastes with simultaneous concentration of radioisotopes which are then immobilized by bonding with asphalt, concrete or glass. The described technique has been utilized in the Institute of Chemistry and Nuclear Technology and in the Institute of Nuclear Energy (Poland) for the condensation of model and real radioactive wastewaters containing ${ }^{51} \mathrm{Cr},{ }^{60} \mathrm{Co}$ and 
${ }^{137}$ Sc [44]. Polyethyleneimine, microcrystallic chitozane and copper ferricyanide, and the formed complexes were separated on the capillary membrane from polysulphone. At $\mathrm{pH}=7$, high decontamination coefficients were obtained, both with respect to model and real wastewaters.

\section{LANDFILL LEACHATE TREATMENT}

Landfill leachates pose a considerable hazard to environment. Their loading, high content of organic substances, frequently changing composition and volume make the treatment of these wastewaters much more difficult than the treatment of municipal wastewaters [45]. Overall strategy of the treatment of landfill leachate is difficult to specify in general terms due to different composition, dumping site and age of the wastes [67].

The following process systems are currently suggested for the treatment of landfill leachate [46]:

- biological pretreatment involving nitrification and denitrification physicochemical treatment by means of flocculants and active carbon; the remaining part is dehydrated and removed as hazardous waste,

- two-stage treatment with the use of reverse osmosis (I - tubular modules; II - spiral modules); neutralization of retentate involving evaporation process, drying and disposal as hazardous waste,

- methods associating biological treatment involving nitrification and denitrification with reverse osmosis (tubular modules); neutralization of retentate involving evaporation process, drying and disposal as hazardous waste.

\subsection{APPLICATION OF REVERSE OSMOSIS}

The application potentials of this technique for the treatment of landfill leachates have currently been investigated $[7,10,36,45,46]$. The method of reverse osmosis does not lead to the neutralization of wastes; most frequently, the wastes are concentrated and returned to the dump, and the recovered and treated water may be released to surface waters or to a sewage system.

Figure 16 presents a two-stage system of reverse osmosis used in the treatment of landfill leachates from the dump at Wijster in Holland [1], whereas Table 16 provides data involving the effectiveness of this system [1].

Pretreatment is recommended in the form of filtration through sand filters or drum-type filters to ensure the protection of pumps, membranes and measurement equipment against destruction.

The quality of permeate should correspond with respective requirements involving the release of wastewaters to environment. It should be controlled by a respective selection of volumetric capacity of the permeate $C_{\mathrm{FV}}$. If the permeate is to be returned 
to the dump, the value of the $C_{\mathrm{Fv}}$ parameter is 5 , which is appropriate in view of economic reasons [46]. But if the retentate has to be utilized by means of a thermal method, the value $C_{\mathrm{Fv}}$ can be higher than 5 , which contributes to the reduction of costs involving this process [46]. If the reverse osmosis concentration process is limited by high concentration of calcium or iron compounds as well as by high concentration of ammonia nitrogen or organic chlorine compounds, the economics of the reverse osmosis applied to the treatment of raw effluents may be questioned.

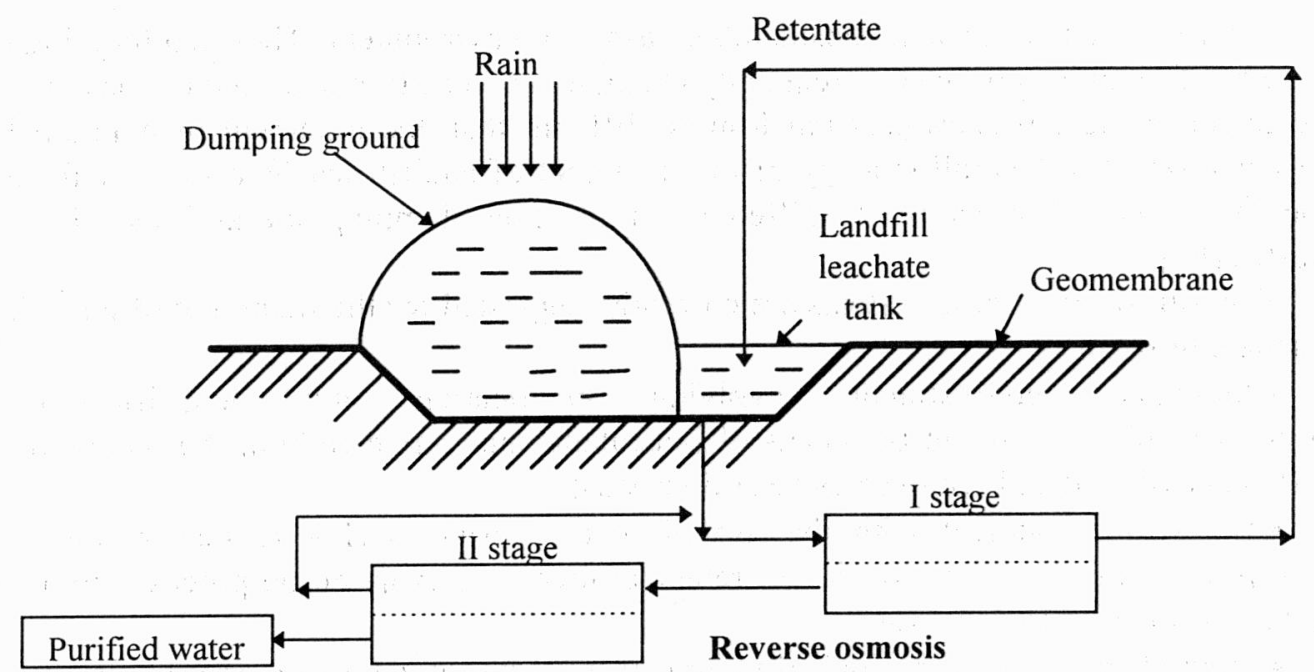

Fig. 16. Diagram of landfill leachate treatment with the use of reverse osmosis

Table 16. Effectiveness of the two-stage osmosis system for the treatment of landfill leachate at Wijster (Holland)

\begin{tabular}{|l|c|c|c|}
\hline \multicolumn{1}{|c|}{ Parameter } & $\begin{array}{c}\text { Raw landfill } \\
\text { leachate }\end{array}$ & $\begin{array}{c}\text { Permeate from } 2^{\text {nd }} \text { stage } \\
\text { of reverse osmosis }\end{array}$ & $\begin{array}{c}\text { System } \\
\text { effectiveness (\%) }\end{array}$ \\
\hline BOD $\left(\mathrm{mg} / \mathrm{dm}^{3}\right)$ & 60 & 2 & 93.7 \\
COD $\left(\mathrm{mg} / \mathrm{dm}^{3}\right)$ & 1600 & 8 & 99.5 \\
Nitrogen $\left(\mathrm{mg} / \mathrm{dm}^{3}\right)$ & 480 & 10 & 97.4 \\
Chloride $\left(\mathrm{mg} / \mathrm{dm}^{3}\right)$ & 2250 & 45 & 97.9 \\
$\mathrm{pH}$ & 8.2 & 5.6 & - \\
Capacity $\left(\mathrm{m}^{3} / \mathrm{h}\right)$ & 35 & 27 & - \\
\hline
\end{tabular}

\subsection{TREATMENT OF LANDFILL LEACHATES USING THE INTEGRATED METHOD OF ACTIVATED SLUDGE AND REVERSE OSMOSIS}

The process of reverse osmosis combined with biological treatment turned out to be very effective in the treatment of landfill leachates $[1,36,46,47]$. The biological 
process is aiming at the removal of substances undergoing biodegradation, especially in the case of effluent heavily loaded with organic substances. As a result of reverse osmosis, refractive substances and inorganic salts are removed.

The effluent leaving the biological installation is subjected to further treatment with the use of reverse osmosis. With minimum requirements involving the quality of permeate, a single stage reverse osmosis is sufficient. The application of an integrated system of biological treatment and reverse osmosis is more economical compared to a system where only reverse osmosis is applied, since the permeate flux and/or obtainable volumetric capacity of the permeate are considerably increased. Furthermore, the nitrification process lowers $\mathrm{pH}$ of the pretreated stream and therefore $\mathrm{pH}$ does not have to be adjusted, or the quantity of added acid is considerably reduced. The procedures of membrane cleaning is carried out with detergent solution and citric acid with much lower frequency of membrane cleaning being observed than in the previous method. Modules for reverse osmosis were equipped with tubular membranes from cellulose acetate $(95 \%$ retention coefficient of $\mathrm{NaCl})$ and composite membranes (TFC) of the retention coefficient equalling $99 \%$. The utilization of retentate most frequently consists in the application of a single-stage evaporator with forced circulation of the liquid and drying the concentrate from the evaporator in the drying machine [10]. In effect of the above, solid dry waste suitable for storing is obtained.

Ultrafiltration can also be introduced into the technological cycle for total neutralization of landfill leachates. The ultrafiltration may be here treated as a 'filter' before the reverse osmosis stage, both in the system of biological treatment $[10,36]$ and in the two-stage reverse osmosis [48]. Figure 17 presents the solution concept [36] of the integrated method consisting of the following stages: biological pretreatment and ultrafiltration, reverse osmosis and evaporation of retentate.

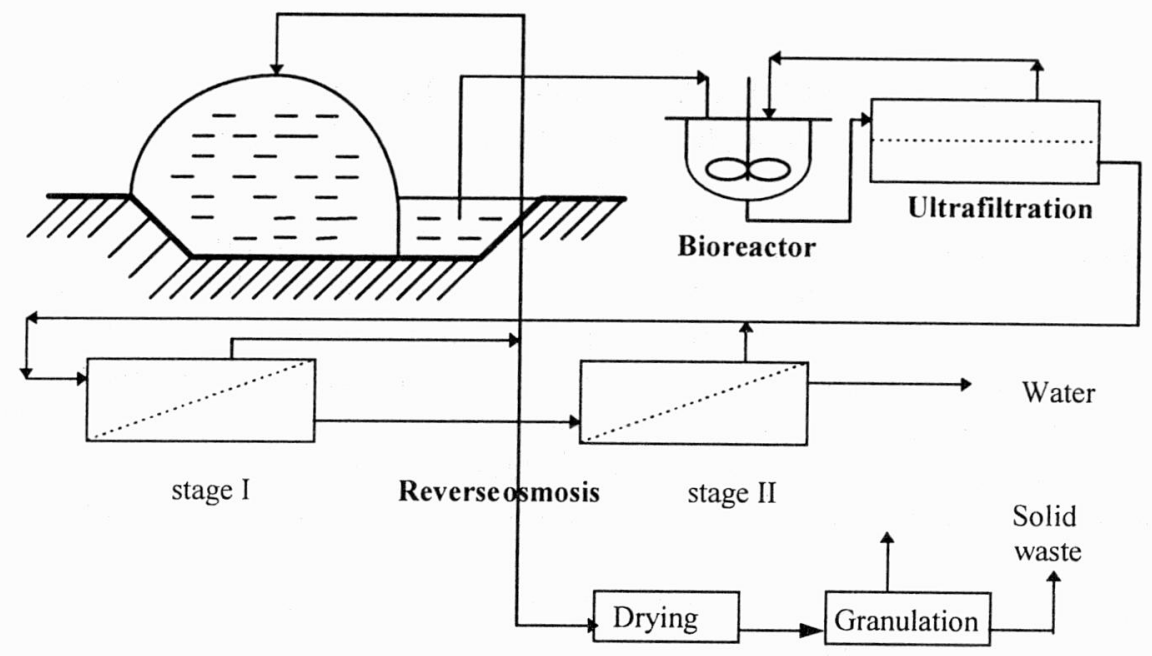

Fig. 17. Treatment of landfill leachates using the integrated biological method and reverse osmosis with the use of ultrafiltration 
In the course of biological treatment, a part of organic compounds undergo biodegradation, whereas the remaining ones together with nitrogen compounds are removed in effect of flocculation. The 1st stage of the process is carried out in the denitrification reactor, in the reactor with activated sludge and in the ultrafiltration system. The purpose of the ultrafiltration process is to remove the activated sludge from the effluent. It also replaces a drum-type filter, biological reactor and settling tank used in the conventional system for the treatment of effluents by means of the integrated biological method and reverse osmosis. Organic refractive compounds and inorganic compounds left after the first stage are removed using the reverse osmosis. The volumetric permeate capacity in the reversed osmosis is $75-80 \%$, and the permeate may be discharged to surface waters. The retentate undergoes recirculation to the dump or is further utilized using evaporation and drying.

The introduction of biological pretreatment into the system for the treatment of landfill leachates with the application of reverse osmosis results not only in the removal of substances undergoing biodegradation, but it also has many other advantages. The most important of them can be itemized as follows [46]:

- only refractive substances remain in the landfill leachate,

- higher permeate fluxes and higher volumetric capacities of the permeate can be obtained in the process of reverse osmosis, because the biofouling of osmotic membranes is eliminated,

- the removal of calcium and iron compounds effected by aeration of the outflow is taking place, which prevents membrane from scale formation,

- nitrogen compounds, which cause problems in the course of concentrate evaporation after reverse osmosis, are removed,

- treatment costs diminish.

\section{TREATMENT OF WASTEWATERS CONTAINING ORGANIC COMPOUNDS WITH THE APPLICATION OF MEMBRANE BIOREACTORS}

In spite of considerable lowering of $\mathrm{COD}$ and $\mathrm{BOD}_{5}$ in the process of biological treatment of wastewaters and of the content of suspensions, the wastewaters still contain refractive, biogenic substances, as well as metabolites of microorganisms which are taking part in the treatment process. One of the examples illustrating the modernization of biological processes of wastewaters is the introduction of ultrafiltration into the technological process. The process which integrates the operation of biological system with this membrane technique is often defined as biomembrane process [49].

In the systems with activated sludge, the first solution is used more frequently. In those systems the biological reactor is coupled with ultrafiltration module in such a way that the whole flux from aeration chamber is passing through the membrane system. The mixture of wastewaters and activated sludge is undergoing concentration in 
this process, since the filtrate released outside is totally devoid of suspension. Ultrafiltration retentate is returned to the aeration chamber, and a part of this retentate may circulate in the cycle, by-passing the biological reactor [9, 49-51]. Figure 18 presents a biomembrane system for the treatment of wastewaters with the use of activated sludge.

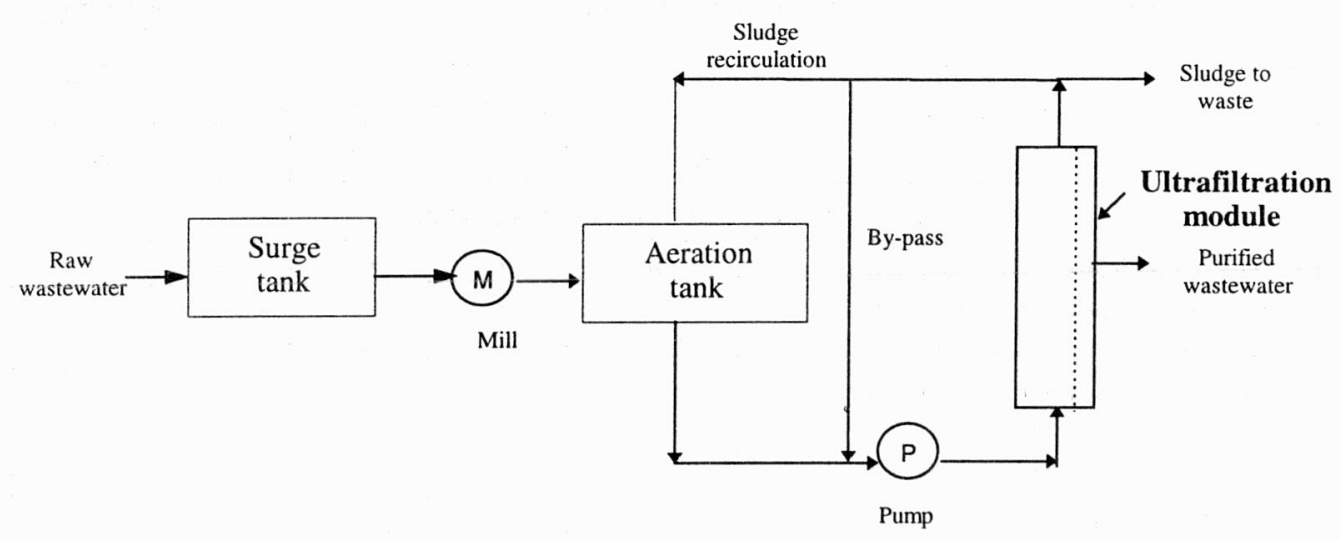

Fig. 18. Diagram of biomembrane water treatment plant operating with the use of activated sludge method

The method of biological treatment is in this case the same as in conventional treatment plants, and the aeration chamber plays the same role in both systems. The functioning of ultrafiltration facility, however, corresponds with that of a secondary settlement tank. Its application enables us to separate biomass from the treated wastewaters, by which the concentration of activated sludge in the aeration chamber can considerably be increased, since the membrane effectively retains the sludge even if the concentration is ten times higher than the concentration permissible for the secondary settlement tanks [52]. Unlike the secondary tanks, the membrane also retains effectively the swelled sludge. The application of presettlement tanks in biomembrane systems is not always necessary, since the sludge can be subject to overloading [50]. In effect of the retention of suspension particles in the system and long retention times for substances whose biodegradation is difficult, $\mathrm{BOD}_{5}$ and $\mathrm{COD}$ in treated wastewaters are also substantially reduced. The total reduction of $\mathrm{BOD}_{5}$ is $95 \%$ with total removal of suspension. The introduction of biomembrane systems was aimed to find such treatment methods of wastewaters, which would combine the advantages of conventional biological treatment plants and the plants utilizing membrane processes and would not have disadvantages of the latter.

Exemplary specification of the results obtained from wastewater treatment in the conventional and biomembrane systems is presented in Table 17 [10]. As indicated, the treated wastewaters from biomembrane systems are totally devoid of suspension, 
and the reduction COD exceeds $99 \%$, which not always can be obtained in treatment plants applying the activated sludge method.

Table 17

Estimated effectiveness of wastewater treatment in conventional and biomembrane systems

\begin{tabular}{|c|c|c|c|c|c|}
\hline \multirow{2}{*}{ Treatment method } & \multicolumn{5}{|c|}{ Treatment efficiency $(\%)$} \\
\hline & Suspension & BOD & COD & $\mathrm{PO}_{4}$ & $\mathrm{~N}_{\text {total }}$ \\
\hline \multicolumn{6}{|c|}{ Two- and three-stage conventional treatment } \\
\hline $\begin{array}{l}\text { 1. Mechanical-biological treatment } \\
\text { 2. Mechanical-biological treatment } \\
\text { with simultaneous removal of phosphates } \\
\text { 3. Mechanical-biological treatment } \\
\text { and chemical treatment } \\
\text { 4. Mechanical-biological treatment } \\
\text { and chemical treatment with denitrification }\end{array}$ & $\begin{array}{l}90 \\
80-90 \\
96 \\
96 \\
\end{array}$ & $\begin{array}{r}90 \\
60-90 \\
96 \\
96 \\
\end{array}$ & $\begin{array}{l}60 \\
40 \\
60 \\
70\end{array}$ & $\begin{array}{l}30 \\
80 \\
90 \\
90\end{array}$ & $\begin{array}{l}20 \\
10 \\
20 \\
80\end{array}$ \\
\hline \multicolumn{6}{|c|}{ Biomembrane system } \\
\hline $\begin{array}{l}\text { 1. Biological treatment (nitrification } \\
\text {-denitrification) with phosphate precipitation } \\
\text { 2. Biological treatment (nitrification } \\
\text {-denitrification) with phosphate } \\
\text { precipitation and coagulation } \\
\text { 3. Biological treatment (nitrification } \\
\text {-denitrification) with phosphate precipitation } \\
\text { and activated carbon adsorption }\end{array}$ & 100 & 99.96 & 90.9 & $>99.8$ & 99.7 \\
\hline
\end{tabular}

Membrane processes, in particular ultrafiltration, may be combined both with the aerobic fermentation and non-aerobic fermentation. The latter method is most frequently applied in the treatment of sanitary wastewaters [10,49], wastewaters generated by the food industry [10] and others containing organic compounds [10, 49]. In aerobic treatment plants, biomembrane systems are combined with various systems whose operation is based on the activated sludge. Table 18 presents the results of wastewater treatment in different biomembrane systems $[9,10]$.

Since ultrafiltration membranes do not fully retain both inorganic salts generated during nitrification and phosphates which should be removed due to eutrophication of water tanks, ultrafiltration is progressively more often combined with the activated sludge method applied in the system which combines nitrification and denitrification [10]. On the other hand, phosphates are removed by the application of chemical precipitation [10] or as a result of absorption on activated sludge [13, 76]. Also reverse osmosis is applied in the removal of these compounds [10]. Ultrafiltration units may 
Results of wastewater treatment in biomembrane systems

\begin{tabular}{|l|c|c|c|c|c|c|}
\hline & \multirow{2}{*}{$\begin{array}{c}\text { Sludge } \\
\text { Applied biomembrane system }\end{array}$} & \multicolumn{4}{|c|}{ Concentration of impurities } \\
& concentration & \multicolumn{2}{|c|}{ in raw/treated wastewaters $\left(\mathrm{mg} / \mathrm{dm}^{3}\right)$} \\
\cline { 3 - 7 } & $\left(\mathrm{mg} / \mathrm{dm}^{3}\right)$ & $\mathrm{SS}$ & $\mathrm{BOD}$ & $\mathrm{COD}$ & $\mathrm{N}$ tot. & $\mathrm{PO}_{4}$ \\
\hline 1. Cascade biomembrane system & 12500 & 12500 & 10200 & 7800 & 4200 & $* *$ \\
& & 0 & 7 & 8 & 15 & \\
& 14000 & 14000 & 9800 & 4600 & 3400 & 960 \\
2. System with phosphate precipitation, & & 0 & $1-3$ & 86 & $10-12$ & $0.5-2.6$ \\
$\mathrm{Mg}(\mathrm{OH})_{2}$ and coagulation & 14000 & 14000 & 9800 & 4600 & 3400 & 960 \\
3. System with phosphate precipitation, & & 0 & $0-2$ & $5-8$ & $<5$ & $0.1-0.15$ \\
$\mathrm{Mg}(\mathrm{OH})_{2}$ and adsorption on bed & 18000 & 10100 & $* *$ & 8800 & 3500 & 300 \\
4. System with coagulation & & 0 & & 7.6 & $1.3 *$ & 0.9 \\
and adsorption column & 12000 & 12000 & $* *$ & 9500 & 3340 & 300 \\
5. System with phosphate & & 0 & & $2-4$ & 15 & $3.0-4.3$ \\
precipitation, CaCl & & 13500 & 4600 & 9600 & 3400 & 940 \\
6. System with precipitation & $* *$ & 0 & 380 & 5 & 18 & 8 \\
and adsorption of phosphates & & 13500 & 4600 & 9600 & 3400 & 940 \\
7. System with precipitation and adsorption & $* *$ & 0 & $70-83$ & $3-5$ & $10-13$ & $0.1-0.15$ \\
\hline
\end{tabular}

*Ammonia nitrogen, ** no data available.

be combined with conventional aeration chambers with a cascade system and with fluidal beds [10].

\section{REFERENCES}

[1] Mulder M., 1994, The use of membrane processes in environmental problems. An introduction, in: Membrane Processes in Separation and Purification (Crepso J.G., Böddeker K.W., Eds.), Kluwer Academic Publishers, Dordrecht-Boston-London, pp. 229-262.

[2] DRIOLI E., 1992, Membrane operations for the rationalization of industrial processes, Water Sci. and Technology, Vol. 25, No. 10, p. 107-110.

[3] Drioli E., Molinari R., 1995, Membrane operations in the management of industrial wastes, in: Towards Hybrid Membrane and Biotechnology Solutions for Polish Environmental Problems (Howell J.A., Noworyta A., Eds.), Wrocław Technical University Press, Wrocław, Poland, pp. 6985.

[4] FANE A.G., 1994, Opportunities and challenges in environmental management with membranes, paper presented during the conference Engineering of Membrane Processes II -Environmental Applications, Italy.

[5] Cheryan M., 1998, Ultrafiltration and Microfiltration Handbook, Technomic Publishing Co., Lancaster.

[6] StrathmanN H., 1991, Economical assessment of membrane processes, in: Effective Industrial Membrane Processes: Benefits and Opportunities (Tuner M.K., Ed.), Elsevier Applied Science, London-New York, pp. 1-19. 
[7] Rautenbach R., Albert R., 1989, Membrane Processes, John Wiley and Sons, New York.

[8] BODZEK M., KONIECZNY K., 1992, The use of ultrafiltration membranes made of various polymers in the treatment of oil-emulsion wastewaters, Waste Management, Vol. 12, pp. 75-84.

[9] JÖNSSON A.S., TRÄGÅRDH G., 1990, Ultrafiltration applications, Desalination, Vol. 77, pp. 135-179.

[10] BODZEK M., BOHDZIEWICZ J., KONIECZNY K., 1997, Membrane techniques in environmental protection, (in Polish), Wydawnictwo Politechniki Śląskiej, Gliwice.

[11] NowORYTA A., 1995, Membrane processes in environmental protection, in: Proceedings of Ist Scientific Conference: Membranes and Membrane Processes in Environmental Protection (Bohdziewicz J., Bodzek M., Eds.), Wisła, Poland, pp. 95-110.

[12] SHEN J.J.S., MIR L., 1982, Reducing energy requirement in latex concentration by ultrafiltration, Ind. Eng. Chem. Prod. Res. Dev., Vol. 21, No. 1, pp. 63-68.

[13] BODZEK M., KONIECZNY K., 1994, Optimization of the ultrafiltration of latex wastewaters, Desalination, Vol. 94, pp. 289-306.

[14] ZaHKa J., MiR L., 1977, Ultrafiltration of latex emulsions, Chem. Eng. Prog., Vol. 73, No. 12, pp. 53-55.

[15] KoniECZNy K., BodzeK M., 1995, Ultrafiltration of latex wastewaters, Desalination, Vol. 104, pp. $75-82$.

[16] AndziaK J., 1983, Paint Coating - Handbook (in Polish), WNT, Warszawa, Poland.

[17] Caetano A.E., Muntau H., De Pinho M.N., 1992, Membrane separation processes application on the treatment of partial effluents of the textile industry, in: Recents Progress an Genie des Procedes, Membrane Processes, Water Treatment - Pervaporation (Aimar P., Aptel P., Eds.), Lavoisier Press, Paris, Vol. 6, No. 21, pp. 169-174.

[18] ScOTt K., 1995, Handbook of Industrial Membranes, Elsevier Advanced Technology, Oxford.

[19] TREFFry-Goatley K., Buckley C., Goves G., 1983, Reverse osmosis treatment and reuse of textile dyehouse effluents, Desalination, Vol. 47, pp. 313-320.

[20] Brandon C., Jernignan D., Caddis J., SPEncer H., 1981, Closed cycle textile dyeing: full scale renovation of hot wash water by hyperfiltration, Desalination, Vol. 39, pp. 301-310.

[21] Calabro V., Pantano G., Kang M., Molinari R., Drioli E., 1990, Experimental study on integrated membrane processes in the treatment of solutions simulating textile effluents. Energy and energy analysis, Desalination, Vol. 78, pp. 257-277.

[22] MAJEWSKA-NOWAK K., WINNICKI T., WIŚNIEWSKI J., 1989, Effect of flow conditions on ultrafiltration efficiency of dye solutions and textile effluents, Desalination, Vol. 71, pp. 127-135.

[23] Calabro V., Drioli E., Matera F., 1991, Membrane distillation in the textile wastewater treatment, Desalination, Vol. 83, pp. 209-224.

[24] Cheryan M., Alvarez J.R., 1995, Food and beverage industry applications, in: Membrane Separations Technology. Principles and Applications (Noble R.D., Stern S.A., Eds.), Elsevier Science, Amsterdam-New York, pp. 415-465.

[25] CHERYAN M., 1991, Membranes in food processing, in: Effective Industrial Membrane Processes: Benefits and Opportunities (Tuner M.K., Ed.), Elsevier Applied Science, London-New York, pp. 157-180.

[26] Kosikowski F.V., 1986, Membrane separations in food processing, in: Membrane separations in biotechnology (McGregor W.C., Ed.), Marcel Dekker, Inc., New York-Basel, pp. 201-254.

[27] Renner E., Abd El Salam M.H., 1991, Application of Ultrafiltration in the Dairy Industry, Elsevier Applied Science, London-New York.

[28] TräGÅRDH G., 1989, Application of membrane technology in food industry, in: Advances in Membrane Phenomena and Processes (Mika A.M., Winnicki T., Eds.), Wrocław Technical University Press, Wrocław, Poland, pp. 249-261.

[29] GRAJEK W., JANKOWSKI T., 1995, Membrane technology in food and agriculture industry, in: Towards Hybrid Membrane and Biotechnology Solutions for Polish Environmental Problems (Howell J.A., Noworyta A., Eds.), Wrocław Technical University Press, Wrocław, Poland, pp. 127-147. 
[30] HANEMAAIJER J.H., 1985, Microfiltration in whey processing, Desalination, Vol. 53, pp. 143-155.

[31] Alfonso M.D., DePINHo M.N., 1991, Membrane separation processes in the pulp and paper industry, Desalination, Vol. 85, pp. 53-58.

[32] TANistRa I., BODZEK M., 1993, Attempts to concentrate and fractionate kraft black liquors by ultrafiltration, Envinorment Protection Engineering, Vol. 18, No. 1-2, pp. 65-80.

[33] TANistra I., BoDzEK M., 1998, Preparation of high purity sulphate lignin from spent black liquor using ultrafiltration and diafiltration processes, Desalination, Vol. 115, pp. 111-120.

[34] ZADORECKI P., 1987, Selection of membranes for treatment of bleaching effluents, Desalination, Vol. 62, pp. 137-147.

[35] FABIANI C., 1992, Metal removal from aqueous wastes by means of membrane hybrid processes, in: Recents Progress an Genie des Procedes, Membrane Processes, Water Treatment - Pervaporation (Aimar P., Aptel P., Eds.), Lavoisier Press, Paris, Vol. 6, No. 21, pp. 211-216.

[36] NOWORYTA A., 1995, Opportunities and challenges in environmental problems with membrane, biotechnology and hybrid processes, in: Towards Hybrid Membrane and Biotechnology Solutions for Polish Environmental Problems (Howell J.A., Noworyta A., Eds.), Wrocław Technical University Press, Wrocław, Poland, pp. 7-27.

[37] StRATHMANN H., 1995, Electrodialysis and related processes, in: Membrane Separation Technology. Principles and Applications (Noble R.D., Stern S.A., Eds.), Elsevier, Amsterdam, pp. 213-281.

[38] Boyadzhiev L., Lazarova Z., 1995, Liquid membranes (liquid pertraction), in: Membrane Separation Technology. Principles and Applications (Noble R.D., Stern S.A., Eds.), Elsevier, Amsterdam, pp. 283-352.

[39] Mulder M., 1991, Basic Principles of Membrane Technology, Kluwer Academic Publishers. Dordrecht.

[40] BOYADZHIEV L., 1990, Liquid pertraction or liquid membranes - state of the art, Sep. Sci. Technol., Vol. 25, pp. 187-205.

[41] Mavrow W., Petrova I., Davarsky K., 1989, UF-25-PAN membrane characteristics in the complexing-ultrafiltration (CUT) process, Environment Protection Engineering, Vol. 15, No. 3-4, pp. 89-94.

[42] Durand G., Rakib M., Stambouli M., MiChelet I., 1993, Application of ultrafiltration assisted by complexation to treatment of industrial waste water containing heavy metals, in: Preprints of ICOM'93 International Congress on Membranes and Membrane Processes, Heidelberg, Germany.

[43] VolcheK K., Keller L., Velicogna D., Wittaker H., 1993, Selective removal of metal ions from ground water by polymeric binding and microfiltration, Desalination, Vol. 89, pp. 247-262.

[44] Chmielewski A.G., Harasimowicz M., Zakrzewska-TrZnadel G., 1995, Application of membrane processes in purification of radioactive wastes, in: Towards Hybrid Membrane and Biotechnology Solutions for Polish Environmental Problems (Howell J.A., Noworyta A., Eds), Wrocław Technical University Press, Wrocław, pp. 227-233.

[45] LEMA J.M., MENDEZ R., BlaSQUEZ R., 1988, Characteristics of landfill leachate and alternatives for their treatment: A review, Water, Air and Soil Pollution, Vol. 40, pp. 223-250.

[46] WEBER B., HOLz F., 1991, Landfill leachate treatment by reverse osmosis, in: Effective Industrial Membrane Processes: Benefits and Opportunities (Tuner M.K., Ed.), Elsevier Applied Science, London-New York, pp. 143-154.

[47] HARRIS J.M., GASPAR J.A., 1988, Management of leachate from sanitary landfills, AIChE Symp. Series, Vol. 84, pp. 171-184.

[48] SYZDEK A.C., AHLERT R.C., 1984, Separation of landfill leachate with polymeric ultrafiltration membranes, Journal of Hazardous Materials, Vol. 9, pp. 209-220.

[49] BODZEK M., DĘBKOWSKA Z., 1991, Biomembrane wastewater treatment containing organic compounds (in Polish), Biotechnologia, No. 3-4(13-14) pp. 74-89. 
[50] Arika M., Kobayahi H., Kinara H., 1977, Pilot plant test of an activated sludge ultrafiltration combined process for domestic wastewater reclamation, Desalination, Vol. 23, pp. 77-86.

[51] BODZEK M., DĘBKOWSKA Z., LITWIN E., 1995, Biomembrane wastewater treatment by activated sludge method, in: Proceedings of International Symposium: Towards Hybrid Membrane and Biotechnology Solutions for Polish Environmental Problems (Howell J.A., Noworyta A., Eds.), Wrocław Technical University Press, Wrocław, Poland, pp. 203-212.

[52] BodzeK M., DĘBKowsKa Z., LobOs E., KoniECZnY K., 1996, Biomembrane wastewater treatment by activated sludge method, Desalination, Vol. 107, pp. 83-95. 